\title{
A Review on Different Cooling/Lubrication Techniques in Metal Cutting
}

\author{
Mst. Nazma Sultana ${ }^{*}$, Nikhil Ranjan Dhar, Prianka Binte Zaman \\ Industrial and Production Engineering, Mechanical Engineering, Bangladesh University of Engineering \& Technology (BUET), Dhaka, \\ Bangladesh \\ Email address: \\ nazma.kuet@yahoo.com (Mst. N. Sultana),nrdhar@ipe.buet.ac.bd (N. R. Dhar), prianka@ipe.buet.ac.bd (P. B. Zaman) \\ ${ }^{*}$ Corresponding author
}

\section{To cite this article:}

Mst. Nazma Sultana, Nikhil Ranjan Dhar, Prianka Binte Zaman. A Review on Different Cooling/Lubrication Techniques in Metal Cutting. American Journal of Mechanics and Applications. Vol. 7, No. 4, 2019, pp. 71-87. doi: 10.11648/j.ajma.20190704.11

Received: December 7, 2019; Accepted: December 23, 2019; Published: December 31, 2019

\begin{abstract}
Various types cooling/lubrication techniques are used in machining processes for enhancing machining performances. Conventional way of cooling/lubrication requires higher coolant cost, waste and disposal cost. Not only has that it had many negative impacts on environment and operators health. For attaining highest efficiency of cutting fluids with minimum quantity, different sustainable strategies are tried to develop. In recent decades researchers are worked out on different cooling/lubrication strategies alternative to conventional cooling. This paper represents a comprehensive review of all presently practiced cooling/lubrication strategies and their effects on different aspects such as surface quality of machined component, tool wear, tool life, cutting temperature, cutting forces etc. through analyzing selected papers. The influence of different cutting fluids such as solid lubricants, nanofluids, ionic liquids etc. with their positive and negative impacts is also discussed. The research gaps are also identified for further research works. From review it is clear that the machining performance is highly affected by cooling techniques and coolant types. Selection of proper cooling technique with suitable cutting fluids depends on work material, tool material and cutting variables.
\end{abstract}

Keywords: Flood Cooling Conventional Cooling, Mist Cooling, High Pressure Cooling (HPC), Minimum Quantity Lubrication (MQL), Nanofluids, Ionic Liquids, Cryogenic Cooling, Hybrid Cooling

\section{Introduction}

Dry machining or machining with no cutting fluids is the most common and clean manufacturing approach but higher cutting variables restrict the applicability of this process. Work hardening, plastic deformation of chips, higher tool wear, poor surface quality are some of the major negative impacts of dry cutting. In dry machining an enormous amount of power is lost due to heat generation between tool surface and workpiece by plastic deformation and by friction between tool/chip on the rake and flank faces. It has been observed that about $20-30 \%$ power is lost due to generation of heat [1]. So, it is clear that necessity of metal working fluids is unavoidable in machining. The major functions of metal working fluids are shown in Figure 1. But in conventional cooling/lubrication the requirement of cutting fluids is approximately $10-100 \mathrm{~L} / \mathrm{min}$ [2] that is needed to minimize for attaining sustainability. In recent years for eliminating or reducing this harmful effects and attaining sustainability, researchers have been trying to improve cooling/lubrication technology alternative to conventional cooling techniques.

Near dry machining (NDM) or minimum quantity lubrication (MQL), cryogenic cooling are some efficient cooling/lubrication techniques alternative to conventional cooling. Applicability of these alternative techniques is described in following sections in brief. Very earlier stages of cutting process, cutting fluids are considered as a substance such as oil or water that can cool/lubricate. Taylor applied water as a cutting fluid in 1907 for machining hard to cut metals with $40 \%$ increased cutting speed [3]. But now many types of cutting fluids such as oil based fluids (straight cutting oil), water based fluids (synthetic, semi-synthetic or emulsion type), gaseous based fluids, solid lubricants, nanoparticles, gels, paste, and aerosols etc. are used for cooling/lubrication. Selection of cutting fluids depends on the complexity of process, workpiece and tool material, cutting variables etc. Cutting fluids having higher heat dissipation ability, proper 
wetting capability, proper formation of lubricating film is considered as a better coolant/lubricant. Gaseous coolants are kept in gas form at room temperature but they are used in machining as high pressurized fluids.

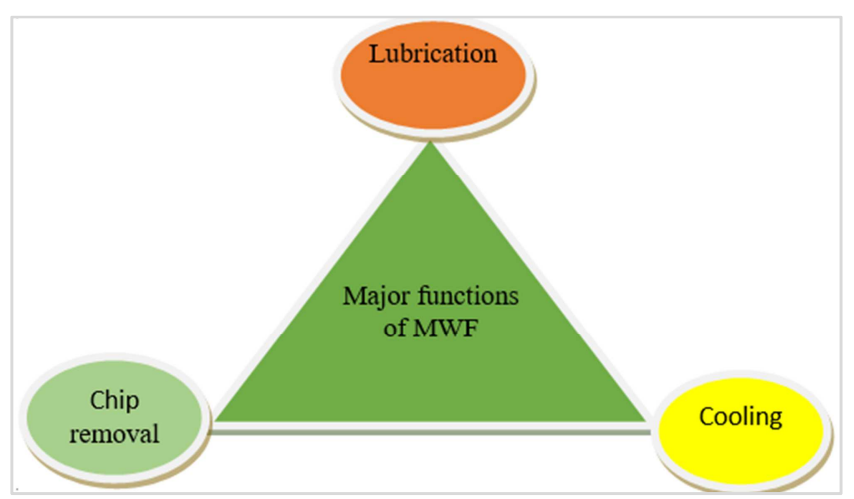

Figure 1. Major functions of metal working fluid (MWF).

Normally argon, helium, carbon-di-oxide, nitrogen are used as gaseous [4]. Higher cost of gas based lubricants restricts its use.

In recent decades researchers have given their focus on increasing the use of biodegradable, nontoxic, environment friendly lubricants/coolants. Recently mineral oils or petroleum based oils are tried to replace for their higher toxicity, non-biodegradability and harmful impacts on environment. Synthetic oils, vegetable oils, solid lubricants, nano lubricants are highly used by researchers. Ionic liquids are tried to use as lubricant additives in cutting processes. Many researchers have already discussed different cooling/lubrication techniques in various machining processes. Chinchanikar and Choudhury [5] provided a literature review on machining hardened steel using coated tools under dry or other cooling/lubrication techniques. Chetan et al. [6] represented a detail review on sustainable techniques to make cutting processes environment friendly and cost effective. Debnath et al. [7] pointed out vegetable oil as bio-based oil and reviewed its development. Minimum quantity lubrication (MQL) and cryogenic cooling are also reviewed. In another review Sharma et al. [8] concluded that systematically application of minimum quantity lubrication (MQL) with nanoparticles can improve productivity and enhances the cutting quality. Benedicto et al. [9] presented a detail technical, economic and environmental impact analysis of cutting fluids in cooling/lubrication in machining. They recommended employing vegetable oils as sustainable cutting fluids with proper treatment. Krolczyk et al. [10] performed a comprehensive analysis on balanced use of cutting fluids for difficult to cut metals such as Titanium, nickel and chromium based alloys machining. They represented a review on ecological trend in machining processes. But this paper presents a comprehensive literature review on recent advancement of alternative cooling/lubrication strategies to conventional cooling with newly developed cutting fluids such as nanofluids, ionic liquids and their effects on machining performances. Moreover hybrid cooling/lubrication techniques are also described in brief which are not available in other previous review works. The reviewed cooling/lubrication approaches are illustrated in Figure 2 and all the short form of used terms are listed in Table 6 with their correct abbreviations.

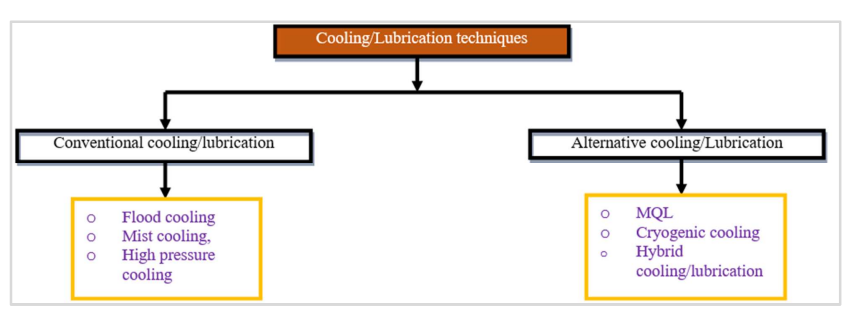

Figure 2. Classifications of discussed cooling/lubrication techniques.

\section{Conventional Cooling/Lubrication Techniques}

Cutting fluid is used as an additive in machining processes for increasing productivity. Various cooling/lubrication approaches are followed for applying cutting fluids into cutting zone. Conventional cooling/lubrication can be grouped into three classes-wet/flood cooling, mist cooling and high pressure cooling (HPC) [7] which are described below.

\subsection{Flood Cooling}

Flood cooling is also named as wet cooling. This process requires cutting fluids approximately $20 \mathrm{~L} / \mathrm{min}$ [11] and in general the tool is flooded with steady flow of cutting fluids in the clearance face under $300 \mathrm{kPa}$ pressure or more for achieving better results [12]. But it is found that operators who are in physical contact in cutting fluid suffer almost $80 \%$ diseases [13]. Flood cooling is now tried to avoid in machining due to higher cost of coolants/lubricants for massive use, negative effects on operators health and environment, complexity of huge waste disposal.

\subsection{Mist Cooling}

In mist cooling water based coolants are mainly applied through a nozzle with high pressurized air to the cutting zone for reducing cutting temperature and increasing tool life. Babic et al. [14] tried to remove the cost and disposal of expensive coolants by mixing air and water as coolant in grinding process. They proved that mist jet cooling is an effective alternative to flood cooling and easier to clean. An et al. [15] studied the effect of cold water mist jet (water at $0^{\circ} \mathrm{C}$ and high pressurized $(0.6 \mathrm{MPa})$ air $(-20))$ cooling on turning Titanium TC9 alloy. They compared this cooling technique with flood cooling and cold air jet based on cutting temperature, tool wear and surface roughness. The higher forced convection, high pressurized jet impingement and vaporization effect accelerates the heat transfer in cold water mist jet cooling. Lv et al. [16] applied pneumatic mist jet cooling in milling burn resistant Ti40 alloy. The required quantity of mist coolant is $96 \mathrm{ml} / \mathrm{min}$ which is smaller than total flood cooling $(2.52 \mathrm{~L} / \mathrm{min})$. At variable cutting speeds 
$(30,60,80,100 \mathrm{~m} / \mathrm{min})$ total flood cooling and pneumatic mist jet cooling was compared based on flank wear, cutting temperature, tool life and material removal volume. All types of wear such as adhesion, micro-chipping, notch wear, coating delamination were reduced except cracks in this new cooling technique. Nandgaonkar et al. [17] performed dry drilling and ester oil based water oil mist spray (WOMS) drilling of Ti6Al4V alloy at $50 \mathrm{~m} / \mathrm{min}$ cutting speed with $167 \mathrm{~mm} 3$ material removal rate using TiAlN coated twist drill. Approximately $66 \%$ higher tool life was achieved in water oil mist spray cooling than dry drilling.

Mist cooling requires less coolant flow so its environment friendliness and efficiency is higher than flood cooling. Now researchers are trying to introduce new type mist coolant such as nitrogen oil mist cooling, cold compressed nitrogen mist cooling etc.

\subsection{High Pressure Cooling (HPC)}

In flood cooling improper penetration of cutting fluid to cutting zone generates higher temperature in machining difficult-to-cut metals at a higher cutting speed. Kaminski and Alvelid [18] pointed out that this higher temperature generates vapor barrier through vaporizing the applied coolant so the cooling effect is reduced. High Pressure Cooling (HPC) is a technique to penetrate the coolant at the cutting zone at higher pressure (5.5 35MPa) through nozzle [7]. Ezugwu and Machado [19] used HPC supply of coolant at 14MPa pressure for machining Inconel 901 alloy for eliminating the built up edge chips formations and after successful implementation better tool lives with no built up edges was found. The equipment's required for HPC installation are high pressure pump, high pressure tubing and an outlet nozzle attached to side of tool holder. The high pressurized jet can be applied in two ways: external cooling and internal cooling [20]. Colak [21] applied high pressure cooling in $\mathrm{Ni}$ based alloy machining and found that pressure of coolant has a strong relationship with flank wear. The author also pointed out that high pressurized coolant flow reduces temperature and cutting force through proper penetration at deeper cutting zone so tool wear is reduced. Colak [22] again studied the performance of HPC in turning of Titanium alloy in respect of tool life, material removal rate and surface roughness. Only tool life was almost $112 \%$ higher in HPC at 300 bar coolant pressure than flood cooling. Kramar and Kopac [20] conducted an experiment for showing the effect of jet pressure and flow rate in machining C45E steel and Inconel 718. For both metals machining, conventional cutting speeds and coated tools were used. Under these conditions HPC increased tool life and chips breakability. Xu et al. [23] experimentally showed the cooling mechanism of high pressure cooling (HPC) using finite element modeling (FEM) and the effect of pressure on tool wear, cutting force and chip structure. It is pointed out that with increasing pressure rate air bubbles disappear from tool surface and $22 \%$ temperature was reduced with $89 \%$ increased tool life at $10 \mathrm{MPa}$ jet pressure. Alaxender et al. [24] concluded that HPC minimizes $50 \%$ consumption of cutting fluid and also reduces cutting temperature and cutting force. Cayli et al.
[25] designed a special jet guidance geometry tool for increasing energy efficiency of HPC in machining hard to cut metals Inconel 718 and Ti6Al4V. The experimental results revealed that the modified jet guidance geometry reduced $41 \%$ tool temperature than conventional tool. The authors pointed out that efficiency of energy consumption can be achieved through proper adjustment of flow rate and pressure of coolant with minimum consumption of hydraulic power and electric power. Alagan et al. [26] checked out the performance of HPC using different textured carbide tools. The results showed that combination effect of texturing at both rake face with dimples and flank face with pyramids provides $30 \%$ better tool life in machining alloy 718 under experimental conditions. Busch et al. [27] performed a comparative analysis among HPC, cryogenic cooling and aerosol dry cooling (ADL). The researchers noticed that at higher cutting speed highest tool life was achieved using HPC but in contrary energy consumption was highest in HPC so this cooling was suggested for roughing operations. Sørby and Vagnorius [28] claimed that HPC cooling technique is unable to increase tool life, minimize notch wear and edge chipping as well as to reduce cutting force in machining Inconel 625 using ceramic insert under $5-15 \mathrm{MPa}$ coolant pressure at $200-300 \mathrm{~m} / \mathrm{min}$ cutting speed. They concluded that HPC technique is not suitable for machining using ceramic tools. Ezugwu and Bonney [29] performed HPC at a pressure of 11-20MPa on Inconel 718 machining with $\mathrm{SiC}$-whiskers reinforced ceramic tools. The result concluded that HPC is responsible for severe edge notching, shorter tool life, increasing cutting force with improving chip breakability. In another paper, Ezugwu et al. [30] performed HPC repeatedly under finishing conditions and showed that tool life is increased within 11-15 $\mathrm{MPa}$ pressure and dropped at a pressure $20 \mathrm{MPa}$ with cutting speed $300 \mathrm{~m} / \mathrm{min}$.

From discussed review it is clear that due to higher pressure HPC facilitates breakability of chips, reduces tool wear and cutting temperature, increases tool life and productivity. HPC is mainly suggested for machining hard to cut metals due to its higher cost. Tool geometry and texturing are also influential in HPC.

\section{Alternative Cooling/Lubrication Techniques}

The development and effect of different cooling/lubrication techniques alternative to conventional cooling are discussed in this section.

\subsection{Dry Machining}

The growing demand of sustainable machining drives researchers to find out promising cooling/lubrication techniques. In today's manufacturing world dry machining is gaining more importance for avoiding health hazards caused by coolants or lubricants. But in most practical situations tool wear is drastically increased with increasing cutting speed because of higher heat which is generated from $99 \%$ energy consumption of tool during 
plastic deformation [31]. Raykar et al. [32] investigated the comparative effects of dry cutting and cutting with suitable coolant on surface topography of EN8 and found no significant difference for surface roughness between these two techniques. They pointed out that dry cutting may be performed under favorable cutting condition. Rubio et al. [33] performed dry machining and MQL with different flow rates on magnesium UNS M11917 pieces for comparative analysis based on surface roughness. At low feed rates MQL provided better surface finish with $4.5 \mathrm{ml} / \mathrm{h}$ flow rate but with increasing feed rate dry machining produced better surface quality than MQL. Dry machining of Aluminum alloy is another critical task because of its low melting point and higher ductility. Aluminum adheres to tool material and built up edge is formed in absence of cutting fluid. During dry cutting of Aluminum alloy wear such as adhesion, built up layer (BUL), built up edge are formed more drastically at higher cutting condition [34]. So special attention must be provided for selection of tool materials, tool geometry, coating materials in case of machining difficult to cut materials where extreme heat, tool wear is generated. C. Bermudo et al. [35] performed parametric analysis of dry turned UNS A-97075 alloy using uncoated WC-CO insert. No regular relation between feed and ultimate tensile strength was observed. In recent years coating technology is becoming more attractive alternative to conventional cooling/lubrication not only for assuring sustainable machining but also for increasing tool life and surface integrity of work materials especially for difficult to cut metals. Davoodi B. et al. [36] claimed that using coated carbide insert for aluminum alloy can be turned without use of cutting fluids through experimentation. Devillez et al. [37] demonstrated that dry machining of Inconel 718 by coated tool at $60 \mathrm{~m} / \mathrm{min}$ cutting speed, $0.1 \mathrm{~mm} / \mathrm{rev}$ feed and $0.5 \mathrm{~mm}$ depth of cut can provide better surface quality with acceptable microhardness and no significant microstructure alteration was found. Venkatesan and Thakur [38] investigated the surface integrity of Nimonic 263 alloy in dry machining using Physical Vapor Deposition (PVD) and Chemical Vapor Deposition (CVD) coated carbide inserts. From experimental results it is proved that PVD coated carbide inserts perform better than CVD coated inserts at medium range values of cutting parameters. Besides this coating technology many researchers adopted surface engineering approach for enhancing the property of tool materials by textures. Sugihara et al. [39] developed dimple texture on noncoated WC-CO insert in face milling and represented the comparative analysis between conventional cutting tool and newly designed tool. Experiments were also performed for different textures with their various directions, percentage of area texture, sizes of micro dimples. The results indicated that micro dimples texture provides more versatility. Niketh and Samuel [40] performed drilling under margin textured, flute textured and non-textured carbide drill tools and $10-12 \%$ reduced thrust force was found in dry drilling using margin textured tools.

From above described review results it can be summarized that sustainability of dry machining is highest because no cutting fluid is used. But some limitations such as high rate of wear, higher friction, and poor surface quality, built up edge formation motivate researchers to modify dry machining. Use of different textured tools, application of PVD or CVD coated tools and surface engineering are some of the improvements of dry machining.

\subsection{Minimum Quantity Lubrication (MQL)}

Dry machining is most sustainable but it has some limitations which are already discussed. Minimum Quantity Lubrication (MQL) or Near dry machining (NDM) is one of the most promising solutions to meet this requirements because in Minimum Quantity Lubrication (MQL) or near dry machining (NDM), a minute quantity of fluid $(10-100 \mathrm{ml} / \mathrm{h})$ is sprayed to cutting zone with compressed air [41] which is middle between flood cooling and dry machining. Some researchers [42-43] worked out on optimizing MQL parameters such as droplet size, wetting angle, wettability, nozzle distance, nozzle angle, flow rate etc. are also influential factors for enhancing the spray quality. Many researchers have been analyzing the effect of MQL on tool life, tool wear, surface integrity of work materials, cutting force, specific energy in various machining processes for different materials. Sarikaya and Güllü [44] focused on Taguchi method, RSM and desirability function for identifying the effect of cutting parameters and cooling conditions on surface roughness of AISI 1050 steel. The results narrated that cooling condition has greater impact on surface roughness. Rahim et al. [45] investigated the efficiency of MQL over dry machining in turning of AISI 1045 at higher cutting speed 250 350m/min. The results revealed that in MQL the cutting temperature was reduced $10 \%-30 \%$ and as well as tool chip contact length was reduced $12 \%$ due to proper cooling effect of air consistent aerosol flow, cutting force was reduced by $5 \%$ to $28 \%$ due to lubrication effect of synthetic ester and also thinner chips were produced than dry turning. Better surface quality was achieved in MQL at $200 \mathrm{~m} / \mathrm{min}$ cutting speed. Dureja et al. [46] suggested MQL as an alternative to dry and flood cooling for sticky material stainless steel in case of minimizing tool wear and surface roughness based on experimental and numerical results. Sankar and Choudhury [47] employed dry air cooling, flood cooling and lubrication using minimum quantity cutting fluid in turning highly alloyed steel. Emulsion type mineral oil was used as lubricants. The experimental results revealed that lubrication using minimum quantity cutting fluid may be an economic and eco-friendly alternative to flood cooling. Similarly Nouioua et al. [48] compared the performance of dry, wet and MQL cooling for machining X210Cr12 using CVD coated carbide insert and 23 40\% improvement of tool life was found under MQL. After experimentation they also concluded MQL as a greener, cost effective and safe approach of lubrication. Ekinovic et al. [49] presented an statistical report of costing related to manufacturing and found approximately $15 \%$ cost is related with application and disposal of cutting fluids represented in Figure 3. Using oil on water droplet (mixing ratio $10 \mathrm{ml} / \mathrm{h}$ of oil and $1.7 \mathrm{~L} / \mathrm{h}$ of water) MQL $17 \%$ reduced cutting force in turning of low carbon steel St52-3 was achieved. In drilling chip extraction is a major problem which adversely affects the surface integrity of drilled holes. Brinksmeier et al. [50] applied MQL with 
variable pressures in low frequency vibration assisted drilling and observed chip breaking technique under dry condition, compressed air with variable pressure and compared with MQL. They found that MQL with 6 bar pressure provided highest chip extraction index at lower feed and higher amplitude of low frequency vibration assisted drilling. Tamang et al. [51] analyzed sustainability of dry machining and MQL for machining Inconel 825 alloy. MQL reduced surface roughness, tool wear and power consumption by $10.41 \%, 16.57 \%$ and $8.47 \%$, sequentially than dry machining.

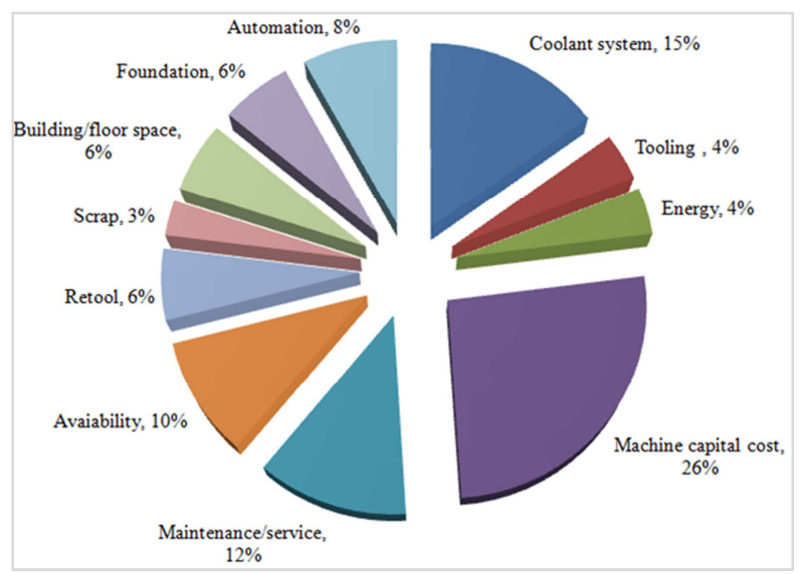

Figure 3. Distribution of manufacturing cost in conventional cooling (Redrawn: Ekinovic et al., 2015).

Khatri and Jahan, [52] investigated different types tool wear in milling Ti6Al4V alloy under dry, MQL and flood cooling techniques and found comparatively less tool wear in MQL. MQL enhances the environmental sustainability as well as other economic aspects. Magnesium alloy is used in aeronautical sectors for its lightness property but its machining is very critical. Water based lubricants may generate flammable atmosphere and higher speed may burn the generated tiny chips. Viswanathan et al. [53] performed turning of magnesium alloy using uncoated carbide insert under dry and MQL and analyzed the results using Taguchi technique and Grey Relational Analysis method. From both statistical analyses better outputs were obtained for MQL. Chetan et al. [54] developed a mathematical model of measuring specific cutting energy under MQL. Validation of model was checked out in case of turning Ni based Nimonic 90 alloy under MQL and it was found that $250 \mathrm{ml} / \mathrm{h}$ flow rate of MQL reduced specific cutting energy $50 \%$ per unit volume of secondary shearing zone due to high pressurized droplet flow into shear zone.) Besides the benefits, MQL has limitations in deep hole drilling, energy intensive processes such as grinding, machining hard to cut metals, proper cooling and chip evacuation process applications [55]. Some researchers found some limitations of MQL in cooling purposes which are also reviewed. Sakharkar and Pawade [56] concluded that MQL provides better lubrication, reduces surface roughness, tool wear but it is not a suitable cooling technique at higher speed. Hadad and Sharbati [57] formed finite element model (FEM) and also experimentally showed that MQL is not able to reduce temperature of grinding process significantly. Chakule et al. [58] performed grinding of high carbon chromium D3 steel under flood cooling and MQL and used soluble oil in both cooling techniques. The authors found that cutting force, cutting temperature and specific energy was lowest for wet cooling than dry and MQL. But better surface quality was achieved in MQL.

From above review results it is clear that MQL is economic and safe lubrication technique but its cooling effect needs to be improved. For enhancing cooling property of MQL in recent years some modifications are executed such as MQL with ionic liquids, MQL with modified vegetable oil, MQL with solid lubricants, MQL with nanofluids and MQL with ionic liquids etc which are described in next sub-sections.

\subsubsection{MQL with Vegetable Oil}

Vegetable based cutting fluid has opened a path to enhance MQL sustainability because it is nontoxic, renewable and easily biodegradable. The anti-wear and friction properties can be increased by proper use of additives. The synthesized vegetable oil has better cooling and lubrication properties. Triglycerides of vegetable oil provide strong lubrication film. Vegetable oil is also a good coolant because of its high heat conductivity $(0.17 \mathrm{~W} / \mathrm{m} . \mathrm{K})$ which is greater than mineral oil $(0.125 \mathrm{~W} / \mathrm{m} . \mathrm{K})$ [59]. All the discussed research works with findings in this section are listed in Table 1.

Table 1. Summary of published research works on Minimum Quantity Lubrication (MQL) using vegetable based oils

\begin{tabular}{|c|c|c|c|c|}
\hline Findings & $\begin{array}{l}\text { MQL using coconut oil (wetting } \\
\text { angle } 33.7^{\circ} \text { ) significant decrease in } \\
\text { friction coefficient, tool wear, along } \\
\text { with favorable chip morphology and } \\
\text { better surface quality of the } \\
\text { workpiece. }\end{array}$ & $\begin{array}{l}\text { Tool life for flood cooling, MQL is } 314 \mathrm{~s} \\
\text { but for air blow is only } 40 \text { s } \\
\text { Tool wear rate is almost same for MQL } \\
\text { and flood cooling so MQL be an } \\
\text { alternative to flood cooling. }\end{array}$ & $\begin{array}{l}\text { Ultimate Tensile strength } \\
\text { is increased } 28 \% \text { at } \\
\text { MQL condition with } \\
260 \mathrm{~m} / \mathrm{min} \text {. The grain size } \\
\text { is finer at MQL than dry. }\end{array}$ & $\begin{array}{l}\text { Wear is reduced in } \\
\text { MQL with } \\
150 \mathrm{~m} / \mathrm{min} \text { speed. }\end{array}$ \\
\hline $\begin{array}{l}\text { Machining } \\
\text { Environment }\end{array}$ & MQL, dry and flood cooling & MQL, flood cooling and air blow & Dry and $\mathrm{MQL}$ & Dry and $\mathrm{MQL}$ \\
\hline $\begin{array}{l}\text { Machining } \\
\text { Process }\end{array}$ & Turning & Drilling & Milling & Turning \\
\hline Coolant types & Coconut oil; Soluble oil & Soluble oil, Synthetic ester, palm oil & Rapeseed oil & LB 2000 \\
\hline $\begin{array}{l}\text { Used } \\
\text { materials }\end{array}$ & AISI 1040 & Ti6Al4V & $\begin{array}{l}\text { Friction stir welded Al } \\
6061\end{array}$ & SAE 1045 steel \\
\hline Authors & Vardhaman et al. (2018) & Rahim and Sasahara (2011) & Al-Wajidi et al. (2018) & $\begin{array}{l}\text { Sampaio et al. } \\
(2018)\end{array}$ \\
\hline
\end{tabular}


Table 1. Continued.

\begin{tabular}{|c|c|c|c|c|c|}
\hline Findings & $\begin{array}{l}\text { Surface quality was } \\
\text { enhanced by MQL with } \\
\text { aloe Vera oil than MQL } \\
\text { with mineral oil. }\end{array}$ & $\begin{array}{l}\text { Better tool life with } \\
\text { less cutting force was } \\
\text { found in MQL with } \\
\text { vegetable oil. }\end{array}$ & $\begin{array}{l}\text { MQCL reduced cutting } \\
\text { temperature and friction } \\
\text { between tool/chip and } \\
\text { tool/work piece. }\end{array}$ & $\begin{array}{l}\text { Modified } \\
\text { jatropha oil } \\
\text { may be an } \\
\text { alternative to } \\
\text { synthetic ester. }\end{array}$ & $\begin{array}{l}\text { Modified jatropha oil with } \\
0.05 \% \text { hexagonal boron } \\
\text { nitride (hBN) reduced } \\
\text { surface roughness, tool } \\
\text { wear, cutting temperature } \\
\text { and cutting force. }\end{array}$ \\
\hline $\begin{array}{l}\text { Machining } \\
\text { Environment }\end{array}$ & MQL & MQL & Dry and MQCL & MQL & MQL \\
\hline $\begin{array}{l}\text { Machining } \\
\text { Process }\end{array}$ & Turning & Milling & Down milling & Turning & Turning \\
\hline Coolant types & Aloe vera oil & Vegetable oil & Bescut 173 & $\begin{array}{l}\text { Jatropha oil, } \\
\text { synthetic ester }\end{array}$ & Jatropha oil and synthetic ester \\
\hline Used materials & M2 steel & Waspaloy & Inconel 718 & AISI 1045 & AISI 1045 \\
\hline Authors & Agarwal and Patil (2018) & Yildrim et al.(2017) & Zhang and Wang (2012) & $\begin{array}{l}\text { Talib and Rahim } \\
(2015))\end{array}$ & Talib and Rahim (2018) \\
\hline
\end{tabular}

(Rahim and Sasahara [60] analyzed the efficiency of MQL using palm oil over MQL with synthetic ester and flood cooling in High speed drilling of titanium alloy. The study enlightened the efficiency of MQL over air blow and flood cooling. The study also pointed out that heat generation; torque and cutting force are lower for MQL using palm oil than MQL using synthetic ester because of higher viscosity of palm oil $(40 \mathrm{~mm} 2 / \mathrm{s})$. Yildrim et al. [61] compared the efficiency of vegetable oil over synthetic, mineral and mineral-synthetic oils with different flow rates in milling using Taguchi approach.

Analytical results showed that vegetable oil provides better tool life and less cutting force than other selected oils. In MQL tool life was $314 \mathrm{~s}$ which was only 40 s for air blow cooling. Actually this result proves that proper penetration of small quantity of oil can reduce the temperature highly than air blow where lubrication and cooling effect is very poor. Cooled air is supplied as add-ons in MQL for improving its cooling properties. Zhang and Wang [62] performed end milling of Inconel 718 under dry condition and MQL with compresses cooled air or MQCL using vegetable oil as a base oil. The experimental results showed that tool life is approximately 1.57 times larger of MQCL than dry milling and lower cutting force is achieved due to superior cooling and lubrication. Al-Wajidi et al. [63] evaluated that MQL with rapeseed oil improve the microstructure of friction stir welded (FSW) Al 6061 alloy and increases the ultimate tensile strength almost $28 \%$ than dry machining. Sampaio et al. [64] have been doing their experiments on MQL with LB2000 vegetable based cutting fluid for induction hardened SAE 1045 steel machining and found reduced wear. Agrawal and Patil [65] experimentally investigated the performance of non edible aloe-vera oil and compared with mineral oil in turning molybdenum high speed steel M2. Experimental results reveal that MQL using aloe vera oil provides $0.14 \%$ reduction of tool wear and $6.7 \%$ reduction of surface roughness. Vardhaman et al. [66] applied coconut oil as a cutting fluid in MQL and performed a comparative analysis among dry, wet, and coconut oil, MQL with soluble oil and MQL with coconut oil. The researchers also concluded that the lubrication property is higher for coconut oil because wettability area of coconut oil droplet is more than the rest of oils in experiment. Various types of vegetable oil are available in commercial market so selection of suitable one is critical. For plain grinding of nickel base alloy GH4169 seven types of vegetable oil such as castor oil, palm oil, corn oil, soybean oil, sunflower oil, rapeseed oil and peanut oil are analyzed. Noticeable point is that viscosity has significant influence on heat transfer and energy ratio coefficient. Talib and Rahim [67] chemically modified crude jatropha oil to trimethylopropane ester (modified jatropha oil) and proved that this modified oil be a substitute of synthetic ester in MQL. In another research, Talib and Rahim [68] added hexagonal boron nitride (hBN) in different percentages and achieved better machining performance from modified jatropha oil with $0.05 \%$ wt. additives.

Growing demand of biodegradable cutting fluids enhances the application of vegetable based MQL which may be an alternative to conventional cooling/lubrication. Vegetable oils provide better lubricant film layer due to its triglycerides structure. It also reduces frictional coefficient and accelerates wear resistance. But the thermal instability and higher cost of vegetable oils are some of the remarkable drawbacks.

\subsubsection{MQL Using Solid Lubricants}

One of the main limitations of MQL is sudden vaporization of cutting fluids at cutting zone before proper cooling and lubrication which affects highly tribological performances. So, effective cooling and lubrication is required at higher cutting speed, feed and depth of cut. In industrial applications higher productivity with environment friendly cutting fluid in economic way is the main concern. Application of solid lubricants such as MoS2, WS2, TiC, $\mathrm{TiN} \mathrm{TiB}_{2}$, graphite, $\mathrm{HBN}$, boron oxide, PTFE etc. is one of the remarkable improvements of MQL [69]. Many researchers studied the influence of solid lubricants in MQL and analyzed their performance on various machining aspects. Some selective studies of researchers are shown in Table 2 Paturi et al. [70] analyzed surface quality of Inconel 718 under pure MQL and MQL with micron sized WS2 particles $(0.5 \%$ wt.) with emulsifier oil in MQL $(200 \mathrm{ml} / \mathrm{hr})$ at a mixing ratio $20: 1$ and observed 35\% improved surface quality than MQL in turning. The anisotropic layer structure and the presence of transition metal dichalcogenide in WS2 reduced tool chip contact friction and heat generation which effectively lubricated the 
work surface. Gunda et al. [71] performed a comparative analysis among dry, flood cooling, MQL (flow rate $42 \mathrm{ml} / \mathrm{hr}$ ) and high pressurized $(0.6 \mathrm{MPa})$ solid assisted MQL (flow rate $60 \mathrm{ml} / \mathrm{hr}$ ). This high pressure helps to penetrate cutting fluid in the closest zone of tool/workpiece and tool/chip interfaces. Solid lubricants formed a thin lubrication film layer at higher temperature and flow of solid lubricants at cutting zone reduced plastic contact between tool and workpiece. As a result better surface and less tool wear with higher tool life (34min) was achieved in high pressurized solid assisted MQL at $100 \mathrm{~m} / \mathrm{min}$ cutting speed turning. High pressurized cutting fluid also improves chips breakability. Marques et al. [72] applied two types of solid lubricants $20 \%$ (MoS2, graphite) with vegetable oil LB2000 in MQL (0.5MPa pressure and $40 \mathrm{ml} / \mathrm{hr}$ flow rate) for turning Inconel 718 at higher cutting speed $250 \mathrm{~m} / \mathrm{min}$ and concluded that $\mathrm{MoS} 2$ solid particles assisted MQL would be better lubrication than graphite solid particles assisted MQL. In reality, for both solid lubricants reduction of flank wear, surface roughness and no residual stress was found due to lamellar structure of graphite and $\mathrm{MoS}_{2}$. Sterle et al. [73] measured coefficient of friction between AISI 1045 and uncoated carbide tool pair using an open tribometer. Different cooling techniques were applied and compared based on coefficient of friction at different cutting speeds $(50,100,150,150,200 \mathrm{~m} / \mathrm{min})$. More robust result was found for MQL with solid lubricants $(10 \mu \mathrm{m}$ sized, particles suspended into isopropyl alcohol flow rate $200 \mathrm{ml} / \mathrm{hr}$ ).

From review analysis it is clear that solid lubricants help to reduce friction between interfaces, improve tool life through reducing tool wear, increase material removal rate, productivity, and enhance the quality of final product. High cost, apply and disposal complexity limit the use of solid lubricants to specific machining processes. More studies are needed for improving the performance of solid lubricants.

Table 2. Summary of published research works on Minimum Quantity Lubrication (MQL) using solid lubricants.

\begin{tabular}{|c|c|c|c|c|}
\hline Findings & $\begin{array}{l}35 \% \text { reduction of surface } \\
\text { roughness is achieved in } \\
\text { solid particles assisted } \\
\text { MQL. }\end{array}$ & $\begin{array}{l}\text { Solid lubricants reduce } \\
\text { tool wear and surface } \\
\text { roughness than wet, } \\
\text { dry and MQL. }\end{array}$ & $\begin{array}{l}\text { Vegetable oil with graphite particles improves } \\
\text { lubrication quality and reduces surface roughness } \\
\text { but higher wear rate is due to lack of oxygen. } \\
\text { MQL with MoS2 solid particles may be considered } \\
\text { as an alternative to dry turning. }\end{array}$ & $\begin{array}{l}\text { Solid lubricants } \\
\text { reduce tool wear } \\
\text { and surface } \\
\text { roughness than } \\
\text { wet, dry and MQL. }\end{array}$ \\
\hline $\begin{array}{l}\text { Machining } \\
\text { Environment }\end{array}$ & $\begin{array}{l}\text { MQL, solid lubricant } \\
\text { assisted MQL }\end{array}$ & $\begin{array}{l}\text { High Pressure Minimum } \\
\text { Quantity Solid Lubricant } \\
\text { cooling }\end{array}$ & MQL, solid lubricant assisted MQL & $\begin{array}{l}\text { Dry, wet, cryogenic } \\
\text { cooling, MQL with } \\
\text { cryogenic, MQL } \\
\text { with solid lubricants }\end{array}$ \\
\hline $\begin{array}{l}\text { Machining } \\
\text { Process }\end{array}$ & Turning & Turning & Turning & Sliding \\
\hline Coolant types & $\begin{array}{l}\text { Emulsifier oil based cutting } \\
\text { fluid, WS2 solid particles }\end{array}$ & $20 \%$ MoS 2 with SAE oil & $\begin{array}{l}\text { Vegetable based oil with graphite }(25-27 \mu \mathrm{m}) \text { and } \\
\text { MoS2 }(5-7 \mu \mathrm{m})\end{array}$ & MoS2 \\
\hline $\begin{array}{l}\text { Used } \\
\text { materials }\end{array}$ & Inconel 718 & Mold steel & Inconel 718 & AISI 1045 \\
\hline Authors & Paturi et al.(2016) & Gunda et al.(2016) & Marques et al.(2019) & Sterle et al.(2018) \\
\hline
\end{tabular}

\subsubsection{MQL Using Nanofluids}

In case of high speed machining conventional fluids perform as better lubricants but their poor thermal properties restrict their use [74]. To overcome this problem nanometer sized particles are used as additives with conventional cutting fluids [75]. Suspending nanoparticles in base oils enhance the properties of cutting fluids such as viscosity, wettability, heat conductivity and convectivity [76].

This newer cutting fluid provides better thermal properties and creates better chemical tribofilm between interfaces of tool and workpieces that enhances the anti-friction or anti-wear performances. Some published research works on nanofluids are selected in random and listed in Table 3 Uysal et al. [77] conducted experiments in milling of martensitic stainless steel under pressurized air mist with MoS2 nanoparicles at different flow rates. The experimental results proved that MQL with MoS2 nanoparicles enhances the reduction of initial tool wear than MQL without nanoparticles and higher flow rate of air mist provides better results in all MQL. Proper selection of nanoparticles is an important issue. Rabiei et al. [78] investigated the properties of six types water based nano cutting fluids. $\mathrm{TiO}_{2}, \mathrm{SiO}_{2}$ and $\mathrm{Al}_{2} \mathrm{O}_{3}$ are efficient as lubricants and $\mathrm{CuO}, \mathrm{NiO}$, Multi-walled carbon nano tube (MWCNT) are suitable as coolants. $\mathrm{Al}_{2} \mathrm{O}_{3}$ was found the best nano lubricant among these six types for grinding 52100 hardened steel. Minimum grinding force and grinding temperature were achieved for $\mathrm{Al}_{2} \mathrm{O}_{3}$ nanoparticle assisted MQL. Wang et al. [79] analyzed the effect of workpiece material and nanofluid types on grinding performances. The results revealed that $\mathrm{Al}_{2} \mathrm{O}_{3}$ nanofluid is suitable for hard material Inconel 718 and $\mathrm{MoS} 2$ is better for soft carbon steel AISI 1045. Eltaggaz et al. [80] performed a comparative analysis between pure MQL and MQL with nanofluids. In experiments $0.4 \%$ wt. $\mathrm{Al}_{2} \mathrm{O}_{3}$ gamma nano particles were added with vegetable oil. These nanofluids provided better thermal conductivity and lubrication properties than pure base oil and flank wear rate was also reduced in nanofluid based MQL. Gutnichenko et al. [81] added graphite nanoparticles ( $\sim 30 \mathrm{~nm}$, $0.2 \%$ vol.) with rapeseed vegetable oil in turning alloy 718 . This modified vegetable oil increased the efficiency of MQL in terms of process stability, surface quality, cutting force and tool wear. Sustainability assessment is a qualitative optimization tool for assessing the sustainability indices of experimental trials. Hegab et al. [82] performed MQL with additives at different weight percentages and without additives 
for assessing sustainability based on power consumption, surface quality, personnel health, safety and environmental effect in turning Inconel 718 alloy. Slight differences are found between experimental optimum results and sustainable optimum parameters.

Better lubrication and heat dissipation qualities may be enhanced by using hybrid nanofluids. Zhang et al. [83] analyzed the effect of different sized $(70,50,30 \mathrm{~nm})$ nano-particles ( $2 \%$ vol.) for grinding Inconel 718 . Mixing of $30 \mathrm{~nm}$ sized $\mathrm{Al}_{2} \mathrm{O}_{3}$ with $70 \mathrm{~nm}$ sized $\mathrm{SiC}$ provided better surface quality than other mixing ratios. Zhang et al. [84] studied the effect of pure nanoparticles (pure MoS2, pure CNT) and mixture of two or more nanoparticles (MoS2/CNT) with different mixing ratio $(1: 1,1: 2,1: 3,2: 1)$. Due to synergistic effect $6 \%$ wt. hybrid nanoparticles MoS2/CNT with mixing ratio (2:1) provided minimum surface roughness and coefficient of friction. Normally tool wear progresses highly at the initial stage of machining that has a detrimental effect on the process. Sharma et al. [74] mixed graphene and alumina at volume concentration ratio (10:90) and tested for different volume concentration of nanoparticles. Hybrid alumina graphene nanoparticles reduce cutting temperature, improve surface integrity and also minimize tool wear. Lv et al. [85] investigated machining and tribological characteristics of MQL in milling process using hybrid (graphene oxide $(\mathrm{GO}) /$ silicon dioxide $\left.\left(\mathrm{SiO}_{2}\right)\right)$ nanofluids in different concentration. After investigation mixing concentrations of $0.02 \%$ wt. $\mathrm{GO}$ and $0.5 \%$ wt. $\mathrm{SiO}_{2}$ with vegetable oil provided best lubrication with minimum worn scar diameter and coefficient of friction. In another research (Rabiei et al. [86] achieved $27.3 \%$ reduction of friction coefficient for hybrid $\mathrm{Al}_{2} \mathrm{O}_{3} /$ multi-walled carbon nano tube (MWCNT) nanofluids in grinding of $100 \mathrm{Cr} 6$ hardened steel. It is clear from review that nanofluids improve machining performance significantly but more studies are needed for finding the optimum size of nanoparticles and its concentration ratio in base oil.

Table 3. Summary of published research works on Minimum Quantity Lubrication (MQL) using nanofluids.

\begin{tabular}{|c|c|c|c|c|c|c|c|}
\hline Findings & $\begin{array}{l}\text { MQL with } \\
\text { nanofluid } \\
\text { improves } \\
\text { heat } \\
\text { dissipation } \\
\text { and tool life. }\end{array}$ & $\begin{array}{l}\text { Higher percent } \\
\text { nano additives } \\
\text { increase tool } \\
\text { wear due more } \\
\text { internal colloidal } \\
\text { collision. } \\
2 \% \text { weight } \\
\mathrm{MWCNT} \text { and } \\
\mathrm{Al}_{2} \mathrm{O}_{3} \text { provides } \\
\text { better results. }\end{array}$ & $\begin{array}{l}\text { Smaller size of } \\
\mathrm{Al}_{2} \mathrm{O}_{3} \text { provides } \\
\text { better surface } \\
\text { quality but } \\
\text { material removal } \\
\text { rate is increased } \\
\text { for larger sized } \\
\mathrm{Al}_{2} \mathrm{O}_{3} \\
\text { nanoparticles } \\
\text { mixing with } \mathrm{SiC} \text {. }\end{array}$ & $\begin{array}{l}\text { Pure Molybdenum } \\
\text { disulphide provides } \\
\text { better lubrication } \\
\text { than pure carbon } \\
\text { nano tube. } \\
\text { Molybdenum } \\
\text { disulphide / carbon } \\
\text { nano tube provides } \\
\text { better lubrication } \\
\text { due to synergistic } \\
\text { effect. }\end{array}$ & $\begin{array}{l}\text { Nanoparticle } \\
\text { assisted } \\
\text { MQL with } \\
40 \mathrm{ml} / \mathrm{h} \text { flow } \\
\text { rate reduced } \\
\text { wear } \\
\text { by } 19.9 \% \text { and } \\
\text { surface } \\
\text { roughness by } \\
22.5 \%\end{array}$ & $\begin{array}{l}\text { Hybrid nano } \\
\text { particles } \\
\text { generate less } \\
\text { tool wear and } \\
\text { surface } \\
\text { roughness than } \\
\text { pure alumina } \\
\text { nanoparticles. }\end{array}$ & $\begin{array}{l}\text { Worn scar } \\
\text { diameter is } \\
\text { reduced and } \\
\text { improved } \\
\text { surface is } \\
\text { achieved } \\
\text { through } \\
\text { using } \\
\text { nanofluids. }\end{array}$ \\
\hline $\begin{array}{l}\text { Machining } \\
\text { Environment }\end{array}$ & $\begin{array}{l}\text { MQL, MQL } \\
\text { with NFs }\end{array}$ & MQL with NFs & MQL with NFs & MQL with NFs & $\begin{array}{l}\text { Dry, MQL, } \\
\text { MQL with } \\
\text { NFs }\end{array}$ & MQL with NFs & $\begin{array}{l}\text { MQL with } \\
\text { hybrid NFs }\end{array}$ \\
\hline $\begin{array}{l}\text { Machining } \\
\text { Process }\end{array}$ & Turning & Turning & Grinding & Grinding & Milling & Turning & Milling \\
\hline $\begin{array}{l}\text { Used } \\
\text { Nanoparticles }\end{array}$ & $\mathrm{Al}_{2} \mathrm{O}_{3}$ & $\mathrm{MWCNT} / \mathrm{Al}_{2} \mathrm{O}_{3}$ & $\mathrm{Al}_{2} \mathrm{O}_{3} / \mathrm{SiC}$ & MoS2 & MoS2 & $\begin{array}{l}\text { Grapheme } \\
\text { nanoplatelets } \\
\text { with alumina }\end{array}$ & $\begin{array}{l}\text { Graphene } \\
\text { oxide/Silicon } \\
\text { dioxide } \\
\text { hybrid } \\
\text { nanoparticles }\end{array}$ \\
\hline $\begin{array}{l}\text { Used } \\
\text { materials }\end{array}$ & ADI & Inconel 718 & Inconel 718 & $\begin{array}{l}\text { GH4169 } \mathrm{Ni} \text { based } \\
\text { alloy }\end{array}$ & AISI 420 & AISI 304 steel & Ti6Al4V \\
\hline Authors & $\begin{array}{l}\text { Eltaggaz et } \\
\text { al.(2018) }\end{array}$ & Hegab et al.(2018) & Zhang et al.(2017) & Zhang et al.(2015) & $\begin{array}{l}\text { Uysal et al. } \\
\text { (2015) }\end{array}$ & $\begin{array}{l}\text { Sharma et al. } \\
\text { (2018) }\end{array}$ & $\begin{array}{l}\text { Lv et al. } \\
(2018)\end{array}$ \\
\hline
\end{tabular}

\subsubsection{MQL Using Ionic Liquids (ILs)}

In recent years it is tried to innovate newer types cutting fluid and MQL with ionic liquids is one of the newer innovative approaches. Ionic liquids are normally liquid salts $\left(<100^{\circ} \mathrm{C}\right.$ temperature) and consist of organic cation and inorganic anion. Like other additives ionic liquids are mixed with base oil at various ratios for enhancing the properties of base oil. Several researchers have already studied the performance of ionic liquids as an additive of cutting fluids and some of them are discussed in Table 4. Davis et al. [87] studied ionic liquids as additive with minimum quantity lubrication for titanium machining and also compared with dry machining and water based MQL (MQL with $\mathrm{H} 2 \mathrm{O}$ ). Ionic liquid was prepared by adding $0.5 \%$ wt. BMIM-PF6 with deionized water in experiments. In this study $60 \%$ tool wear improvement, $15 \%$ lower force in tangential and radial directions was achieved. In another research, Goindi et al. [88] machined AISI 1045 using 1\% wt. three different types ionic liquids BMIM-PF6, BMIM-BF4, BMIM-TFSI individually with vegetable oil and better tribological properties were achieved than dry cutting, dry cutting with compressed air and MQL with vegetable oil. Pham et al. [89] evaluated the process capability and sustainability of ionic liquid. Two types of ionic liquids: EMIM-TFSI and BMIM-I were compared with dry milling, other conventional cutting oils cooling and distilled water cooling. In this experiment BMIM-I provided better surface integrity than others. Sani et al. [90] tested the performance of ammonium based (AIL) and phosphonium based (PIL) ionic liquids with modified jatropha oil (MJO) in machining of AISI 1045 under MQL environment and 
observed that a small quantity of ionic liquids enhances the machining performance highly. The better results were obtained from $\mathrm{MJO}+10 \% \mathrm{AIL}$ and $\mathrm{MJO}+1 \% \mathrm{PIL}$ cutting fluids. Now it can be concluded that ionic liquids enhance the tool wear resistance through tribo-chemical reactions between ionic liquids lubricants and workpiece/tool surface. This lubricant acts as an additive to form a tribo-layer for reducing tool wear and coefficient of friction. Application of ionic liquids as neat lubricants or additives of different base oils is a newer technique of cooling so more detail study is needed.

Table 4. Summary of published research works on Minimum Quantity Lubrication (MQL) using ionic liquids.

\begin{tabular}{|c|c|c|c|c|}
\hline Findings & $\begin{array}{l}\text { Tool wear is reduced by } 60 \% \\
\text { in MQL with ILs than dry } \\
\text { cutting and } 15 \% \text { than MQL. }\end{array}$ & $\begin{array}{l}\text { A minute quantity of ionic } \\
\text { liquids significantly affects } \\
\text { the tribology of machining } \\
\text { process. }\end{array}$ & $\begin{array}{l}\text { BMIM-I ionic liquid } \\
\text { shows less volatility } \\
\text { and provides better } \\
\text { surface. }\end{array}$ & $\begin{array}{l}\text { MJO+10\%AIL and } \\
\text { MJO+PIL provide better } \\
\text { performance than synthetic } \\
\text { ester. }\end{array}$ \\
\hline Machining Environment & $\begin{array}{l}\text { Dry, MQL with water and MQL } \\
\text { with ILs }\end{array}$ & $\begin{array}{l}\text { Dry, MQL, MQL with ILs } \\
\text { and flood cooling }\end{array}$ & $\begin{array}{l}\text { Dry, Flood cooling and } \\
\text { MQL with ILs }\end{array}$ & MQL, MQL with ILs \\
\hline Machining Process & Turning & Turning & End milling & \multirow{4}{*}{$\begin{array}{l}\text { Turning } \\
\text { Modified Jatropha oil (MJO) } \\
\text { with Ammonium based (AIL) } \\
\text { and Phosphonium based (PIL) } \\
\text { ionic liquids, synthetic ester } \\
\text { AISI } 1045 \\
\text { Sani et al. (2019) }\end{array}$} \\
\hline Coolant types & BMIM-PF6 with water & $\begin{array}{l}\text { Vegetable oil with } \\
\text { BMIM-PF6, BMIM-TF4, } \\
\text { BMIM-BFTS }\end{array}$ & EMIM-BFTS, BMIM-I & \\
\hline Used materials & Titanium & AISI 1045 & Al-5052 & \\
\hline Authors & Davis et al. (2015) & Goindi et al. (2015) & Pham et al. (2014) & \\
\hline
\end{tabular}

\subsubsection{Some Other New Features of MQL}

Some other newer techniques such as Contact Charged Electrostatic Spray Lubrication (CCESL) [91], variable time controlled pulse [92], Electrostatic Minimum Quantity Lubrication (EMQL) [93], Ranque Hilsch Vortex Tube (RHVT) in Nitrogen gas assisted MQL (RHVT-NGMQL) [94] are also experimented for enhancing cooling/lubrication.

\subsection{Cryogenic Cooling}

Cryogenic cooling is another alternative sustainable cooling technique. In cryogenic cooling Liquid Nitrogen (LN2) at $-196^{\circ} \mathrm{C}$, carbon dioxide $\left(\mathrm{CO}_{2}\right)$ or dry ice at $-78.5^{\circ} \mathrm{C}$ are used as coolant in cryogenic cooling process. These coolants easily evaporate to atmosphere without any harmful effects. In recent years, effective cooling with clean environment makes this technique popular. Some limitations of cryogenic cooling are the cost of cryogen is high and the performance highly depends on the reliable supply of cryogen. Another important limitation is this technique is better for cooling but not for lubrication.

Based on cryogen type cryogenic cooling has two operating methods-cryogenic cooling with liquid nitrogen (LN2) and cryogenic cooling with dry ice or $\mathrm{CO}_{2}\left(-78.5^{\circ} \mathrm{C}\right)$.

\subsubsection{Cryogenic Cooling with Liquid Nitrogen (LN2)}

Since 1950s liquid nitrogen (LN2) was used as a cryogenic coolant but now its use is increasing rapidly because of its easily evaporation characteristic in nature $(79 \%$ of air is nitrogen) and environment friendliness.

Researchers have been performing many research works on various aspects of cryogenic cooling using liquid nitrogen in different machining processes. Dhar et al. [95-96] experimentally proved that cryogenic cooling by liquid nitrogen jet reduced more chip-tool interface temperature, surface roughness and tool wear for different materials machining than dry machining. Fredj et al. [97] used cryogenic cooling for ground surface improvement of AISI 304 steel. In cryogenic cooling $40 \%$ reduction of surface roughness, better resistance to stress corrosion and pitting corrosion, higher level of work hardening were achieved. Umbrello et al. [98] investigated the effect of cryogenic cooling on the surface integrity of hardened AISI 52100 steel. Research results showed that better surface roughness, finer grain size, reduced white layer regions were achieved in cryogenic cooling than dry machining. Manimaran and Pradeepkumar [99] performed a comparative analysis among dry, wet and cryogenic cooling. The analysis concluded that specific energy, grinding force and surface roughness were reduced satisfactorily in cryogenic cooling than dry and wet. Another remarkable result was that, increasing pressure of cryogen improves surface quality $12 \%$ in cryogenic grinding for this wheel work-piece pair. Dinesh et al. [100] conducted turning experiment on AZ60 magnesium alloy under various cutting parameters and investigated the positive influence of cryogenic cooling on surface integrity, hardness, cutting temperature and cutting force. Shokrani et al. [101] employed cryogenic cooling for cobalt chromium alloy machining and found $71 \%$ reduced surface roughness with $96 \%$ improvement of tool life than conventional cooling. Cryogenic cooling is also proved as better cooling process for hard machining. Chip morphology has an impact on machining performance because long, highly curled chips deteriorate surface quality. Aramcharoen [102] investigated the influence of cryogenic cooling on tool wear and chip morphology in turning titanium alloy. Using conventional cooling at $100 \mathrm{~m} / \mathrm{min}$ cutting speed built up edge was generated after $3 \mathrm{~min}$ turning but within this range of time no built up edge was found in cryogenic cooling. Scanning Electron Microscope (SEM) analysis results showed that helical chips were produced in cryogenic cooling turning but in conventional oil cooling most snarled chips were produced which are highly undesirable. Yousfi et al. [103] focused on the influence of coated tools in cryogenic cooling. $2 \mu \mathrm{m}$ thick $\mathrm{CrN}$ coating provided better results for roughness $0.8 \mu \mathrm{m}$ but unable to prevent adhesion to titanium work material. Isakson et al. [104] agreed with previous other researchers that cryogenic cooling may be applied instead of 
flood cooling without sacrificing surface integrity of titanium alloy.

Mia [105] carried out milling of AISI 1060 steel using HSS insert instead of carbide insert using internal cryogenic cooling. ANOVA results revealed that surface roughness, cutting force and specific cutting energy are highly influenced by cooling followed by feed rate and lastly cutting speed. Internal cryogenic cooling with cutting speed $26 \mathrm{~m} / \mathrm{min}$ and feed rate $58 \mathrm{~mm} / \mathrm{min}$ provided optimum experimental results. Nie et al. [106] performed hard machining of AISI 52100 steel under dry environment and cryogenic cooling. In dry environment white layer formation is drastically increased at higher cutting speed but in cryogenic cooling white layer formation is almost same in varying cutting speeds Mia et al. [107] conducted turning operation of Titanium alloy under dry condition and cryogenic cooling with mono jet and dual jet of liquid nitrogen. In that research, life cycle assessment of cryogenic cooling was performed and the observed result pointed out that the cooling technique has a direct relationship with environmental aspects. In another research, Sivaiah and Chakradhar [108] applied MQL and cryogenic cooling in turning 17-4PH stainless steel for comparative analysis based on tool wear and surface roughness. Cryogenic cooling with liquid nitrogen provided less tool wear and surface roughness and researchers concluded the cryogenic cooling as a clean technique because liquid nitrogen easily evaporates after penetration that agreed with previous described review results. Dhananchezian [109] studied the mechanical characteristics of difficult to cut metal $\mathrm{Ni}$ based Hastelloy C-276 under cryogenic cooling and dry turning. This cooling technique reduced cutting zone temperature $61 \sim 68 \%$, cutting force and surface roughness by $8-33 \%$ than dry turning. Cutting tool performance was also improved through controlling the wear mechanism.

Researchers also discussed some negative results of cryogenic cooling in machining processes. NALBANT and YILDIZ [110] reported cryogenic machining as a poor cooling method for milling AISI 304 steel based on their experimental results. Cutting force, torque is higher in cryogenic cooling than dry technique for used work-piece tool pair in experiments. It is also found that if cutting speed is lower than $200 \mathrm{~m} / \mathrm{min}$ then frittering occurs in cryogenic cooling. It can be pointed out that better performance of cryogenic cooling depends on tool/workpiece pair. Cryogenic cooling using liquid nitrogen enhances rapid cooling, reduces built up edge, abrasive and chemical wear highly. Besides that cryogenic cooling is highly clean and environment friendly cooling technique.

\subsubsection{Cryogenic Cooling with Dry Ice or $\mathrm{CO}_{2} \mathrm{Snow}$}

Applying $\mathrm{CO}_{2}$ flow in liquid form is another technique of cryogenic cooling. Murugappan et al. [111] implemented precooling cryogenic using dry ice and two different types cutting inserts in turning Al 6063. The experimental results showed that insert type and cooling techniques have influential effect on productivity and product quality. Biermann and Hartmann [112] used $\mathrm{CO}_{2}$ cryogenic process cooling for reducing burr formation in drilling of quenched steel 34CrNiMo6 and aluminum alloy AlMgSi1. Cordes et al. [113] performed cryogenic $\mathrm{CO}_{2}$ cooling in which the flank wear was reduced by $63 \%$, cutting temperature was reduced by $55 \%$ and material removal rate was increased by $72 \%$ than dry milling at cutting speed $320 \mathrm{~m} / \mathrm{min}$. Rahim et al. [114] carried out experiment on orthogonal cutting process of AISI 1045 under MQL and super critical $\mathrm{CO}_{2}$ cooling. It was found that super critical $\mathrm{CO}_{2}$ cooling is more efficient for reducing cutting force, tool chip contact length, specific energy, chip thickness and cutting temperature than MQL. Finally, it can be noted that cryogenic $\left(\mathrm{CO}_{2}\right)$ cooling reduces burr formation, minimizes tool wear with uniform wear length, removes white layer formation and improves tool life.

\subsection{Hybrid Cooling/Lubrication Techniques}

Researchers are now aiming to combine two or more cooling strategies for attaining the better synergistic effects of cooling techniques in cutting processes. Pereira et al. [115] proposed new nozzle adapter for combining the effect of MQL and cryogenic $\mathrm{CO}_{2}\left(-80^{\circ} \mathrm{C}\right)$. This new method achieved $93.5 \%$ efficiency of conventional cooling for increasing tool life. Park et al. [116] applied cryogenic cooling (using liquid nitrogen) with MQL using exfoliated graphite nano particles with vegetable oil as base oil for machining titanium alloy and found that this hybrid cooling reduced cutting force and tool wear than conventional cooling. Hybrid cooling (cryogenic cooling with MQL) is considered as a promising alternative to conventional cooling but some research results revealed that th hybrid cooling may be an alternative to MQL not to conventional cooling. Hanenkamp et al. [117] combined $\mathrm{CO}_{2}\left(-78.5^{\circ} \mathrm{C}\right)$ cryogenic internal cooling with $\mathrm{MQL}$ for investigating surface roughness and tool wear in drilling of Ti6Al4V alloy using a rotating tool 50CrMo4. This hybrid cooling reduced $64.5 \%$ surface roughness than MQL but increased $11 \%$ than conventional cooling. Not only that hybrid cooling (cryogenic $\mathrm{CO}_{2}$ with MQL) also provided finer surface zone with no crack and white layer formation and tool wear was also minimized. Iturbe et al. [118] performed turning operation of Inconel 718 for 8-20minutes under dry, conventional cooling and (cryogenic cooling (LN2) $+\mathrm{MQL}$ ). Results revealed that almost four times larger surface damage was found in hybrid cooling due to higher flank wear rate than conventional cooling. The authors concluded that surface quality depend not only cooling process but also tool flank wear. From the review results it can be concluded that hybrid cooling/lubrication technique is now in the introduction stage and further research studies are needed for improving the performance and robustness of hybrid cooling/lubrication techniques.

\section{Conclusions}

In this study, first of all, various cooling/lubrication processes and cutting fluids are introduced and then, effect of this cooling/lubrication processes and cutting fluids on cutting parameters such as, tool- workpiece temperature, cutting forces, surface roughness, tool wear are reviewed. Present analysis shows that not only cooling/lubrication processes 
influence on machining parameters but also type of base fluid and additives, size of additive particles and concentration of additives in base fluid are important too. Review results have shown that dry cutting is environmentally safer, most sustainable and less costly than cutting process with coolants/lubricants but dry cutting is not suitable for cutting processes with higher heat generations. So, further research is needed to remove these limitations of dry cutting. Positive and negative effects of all presently practiced cooling/lubrication strategies are listed in Table 5. To eliminate the bad impacts of conventional cooling methods such as flood cooling, mist cooling and HPC, researchers have tried to apply MQL with different types less toxic and biodegradable cutting fluids. Elimination of mineral oil and other toxic cutting fluids are successfully done by using vegetable oils, nanofluids, ionic liquids etc. Cryogenic cooling is another alternative to conventional cooling which is green, safer, sustainable and efficient but initial cost is higher that limits its use.

\section{Future Scope of Research}

Some points are narrated below for improving cooling/lubrication techniques in future by more research works.

1. Proper selection of coated tools in dry machining of hard to cut metals need to be investigated.

2. Research and development for modifying vegetable oils to overcome its limitations such as low thermal stability and higher oxidation.

3. More and more research is needed for improving the performance of nanofluids through optimizing the size of nanoparticles and mixing ratio into base oils. Hybrid nanofluids are another attractive scope of further research.

Table 5. List of positive and negative impacts of various cooling/lubrication techniques.

\begin{tabular}{|c|c|c|c|c|c|}
\hline & $\begin{array}{l}\text { Huge quantity of } \\
\text { cutting fluid is } \\
\text { applied. Not a clean } \\
\text { cooling technique. } \\
\text { Responsible for } \\
\text { many diseases of } \\
\text { workers. Higher } \\
\text { cost of cutting } \\
\text { fluids. }\end{array}$ & $\begin{array}{l}\text { Mist cooling provides } \\
\text { wet cutting environment } \\
\text { that makes the working } \\
\text { space slippery. Skin } \\
\text { diseases may occur. }\end{array}$ & $\begin{array}{l}\text { Higher amount of fluids are } \\
\text { needed. Surface roughness may } \\
\text { be raised. Recycling cost of } \\
\text { cutting fluid is involved. Fluids } \\
\text { from chips need to be separated. } \\
\text { Cooling environment is not } \\
\text { clean. Inhalation problem may } \\
\text { occur. Energy consumption is } \\
\text { higher. }\end{array}$ & $\begin{array}{l}\text { Poor surface finish and } \\
\text { higher tool wear rate is } \\
\text { found. Increased cutting } \\
\text { temperature. Difficult to } \\
\text { machine hard to cut } \\
\text { metals. Higher cutting } \\
\text { force is found so specific } \\
\text { energy requirement is } \\
\text { higher. }\end{array}$ & $\begin{array}{l}\text { Cheap breakability is poor. } \\
\text { Inhalation problem may } \\
\text { occur through MQL spray. } \\
\text { Proper cooling is not } \\
\text { achieved. Not suitable for } \\
\text { grinding process. }\end{array}$ \\
\hline Positive impacts & $\begin{array}{l}\text { Highly applicable } \\
\text { for energy extensive } \\
\text { processes such as } \\
\text { grinding. }\end{array}$ & $\begin{array}{l}\text { Cheap cooling process. } \\
\text { Cooling ability is higher. } \\
\text { Reduces cutting } \\
\text { temperature. } \\
\text { Environmental } \\
\text { friendliness is higher } \\
\text { than flood cooling. }\end{array}$ & $\begin{array}{l}\text { Tool life is increased highly. } \\
\text { Cooling rate is higher. Easy chip } \\
\text { breakability. Cutting force is } \\
\text { reduced. } \\
\text { Suitable for hard to cut metals } \\
\text { machining. }\end{array}$ & $\begin{array}{l}\text { No cutting fluid is used } \\
\text { so cost is minimum, no } \\
\text { risk of operators health. } \\
\text { Clean machining is } \\
\text { achieved. Easy recycling } \\
\text { due to cleanliness of } \\
\text { chips. }\end{array}$ & $\begin{array}{l}\text { Less consumption of } \\
\text { cutting fluid. So economic } \\
\text { and ecological impact is } \\
\text { minimized. Specific } \\
\text { energy requirement is } \\
\text { minimized. Improved } \\
\text { surface quality and more } \\
\text { sustainable technique. } \\
\text { Clean and green process. }\end{array}$ \\
\hline $\begin{array}{l}\text { cooling/lubricatio } \\
\mathrm{n} \text { processes }\end{array}$ & Flood cooling & Mist cooling & $\mathrm{HPC}$ & Dry machining & MQL \\
\hline
\end{tabular}

Table 5. Continued.

\begin{tabular}{|c|c|c|c|c|c|c|}
\hline Negative Impacts & $\begin{array}{l}\mathrm{CO}_{2} \text { is responsible for global } \\
\text { warming. } \\
\text { Set up and tooling cost, price } \\
\text { of cryogen are higher. }\end{array}$ & $\begin{array}{l}\text { Equipment cost is } \\
\text { higher and set up is } \\
\text { complex than other } \\
\text { cooling/lubrication. }\end{array}$ & $\begin{array}{l}\text { Costs of vegetable oil } \\
\text { are comparatively } \\
\text { higher than } \\
\text { conventional fluids. } \\
\text { Oils must be separated } \\
\text { from chips. }\end{array}$ & $\begin{array}{l}\text { Without addition of } \\
\text { any coolant its } \\
\text { cooling } \\
\text { performance is } \\
\text { poor. } \\
\text { Production process } \\
\text { is costly }\end{array}$ & $\begin{array}{l}\text { Higher cost of } \\
\text { nanoparticles. }\end{array}$ & $\begin{array}{l}\text { Synthesis of ionic } \\
\text { liquids as neat } \\
\text { lubricants or } \\
\text { additives with base } \\
\text { oil is a complex } \\
\text { process. ILS are } \\
\text { costly. }\end{array}$ \\
\hline Positive impacts & $\begin{array}{l}\text { Clean and environment } \\
\text { friendly cooling process with } \\
\text { lubrication through forming } \\
\text { a gas layer between } \\
\text { interfaces. Completely } \\
\text { harmless to operators health. } \\
\text { Improves surface quality, } \\
\text { reduces tool wear and } \\
\text { cutting temperature rapidly. } \\
\text { It also improves chip } \\
\text { breakability. }\end{array}$ & $\begin{array}{l}\text { Cooling and } \\
\text { lubrication } \\
\text { efficiency is } \\
\text { expected be higher. }\end{array}$ & $\begin{array}{l}\text { Nontoxic, } \\
\text { biodegradable and } \\
\text { environment friendly } \\
\text { technique. } \\
\text { Better cooling and } \\
\text { lubrication. } \\
\text { Improved tool life } \\
\text { with less tool wear } \\
\text { can be achieved. }\end{array}$ & $\begin{array}{l}\text { Improves tool life, } \\
\text { reduces shear angle } \\
\text { and tool chip } \\
\text { contact length. } \\
\text { Improves surface } \\
\text { roughness. Reduces } \\
\text { tool chip interaction } \\
\text { through forming } \\
\text { tribofilm between } \\
\text { interfaces. }\end{array}$ & $\begin{array}{l}\text { Deep } \\
\text { penetration of } \\
\text { nanofluids can } \\
\text { be achieved. So } \\
\text { temperature at } \\
\text { the cutting zone } \\
\text { is highly } \\
\text { minimum. }\end{array}$ & $\begin{array}{l}\text { Tool wear and } \\
\text { coefficient of } \\
\text { friction is highly } \\
\text { reduced. Ionic } \\
\text { liquids is recyclable } \\
\text { and in most cases } \\
\text { biodegradable. }\end{array}$ \\
\hline $\begin{array}{l}\text { Name of } \\
\text { cooling/lubricatio } \\
\mathrm{n} \text { techniques }\end{array}$ & Cryogenic cooling & $\begin{array}{l}\text { Hybrid } \\
\text { cooling/lubrication }\end{array}$ & Vegetable based oils & Solid Lubricants & Nanofluids & Ionic liquids \\
\hline
\end{tabular}




\section{Nomenclature}

Table 6. Used short terms with proper abbreviations.

\begin{tabular}{|c|c|}
\hline WOMS & Water in Oil Mist Spray \\
\hline HPC & High Pressure Cooling \\
\hline MQL & Minimum Quantity Lubrication \\
\hline MQCL & Minimum Quantity Cooling Lubrication \\
\hline SQL & Small Quantity Lubrication \\
\hline PVD & Physical Vapor Deposition \\
\hline NDM & Near Dry Machining \\
\hline VO & Vegetable oil \\
\hline NFs & Nanofluids \\
\hline $\mathrm{CNT}$ & Carbon nano tube \\
\hline MWCNT & Multi walled Carbon nano tube \\
\hline $\mathrm{hBN}$ & hexagonal Boron Nitride \\
\hline $\mathrm{SCCO}_{2}$ & Super Critical Carbon-di-oxide \\
\hline LN2 & Liquid Nitrogen \\
\hline $\mathrm{NiO}$ & Nickel oxide \\
\hline $\mathrm{SiO}_{2}$ & Silicon dioxide \\
\hline UAG & Ultrasonic Assisted Grinding \\
\hline ILs & Ionic Liquids \\
\hline BMIM-PF6 & 1-methyl 3-butylimidazolium hexafluorophosphate \\
\hline AIL & Ammonium based ionic liquid \\
\hline GO & Graphene Oxide \\
\hline $\mathrm{SiO}_{2}$ & Silicon dioxide \\
\hline MoS2 & Molybdenum disulfide \\
\hline WS2 & Tungsten sulfide \\
\hline CVD & Chemical Vapor Deposition \\
\hline $\mathrm{TiC}$ & Titanium carbide \\
\hline TiN & Titanium Nitride \\
\hline $\mathrm{TiB}_{2}$ & Titanium diboride \\
\hline PTFE & Polytetrafluoroethylene \\
\hline $\mathrm{Al}_{2} \mathrm{O}_{3}$ & Aluminum oxide \\
\hline $\mathrm{CaF} 2$ & Calcium fluoride \\
\hline $\mathrm{CuO}$ & Copper oxide \\
\hline $\mathrm{SiC}$ & Silicon carbide \\
\hline BMIM-BF4 & 1-methyl 3-butylimidazolium tetrafluoroborate \\
\hline BMIM-TFSI & 1-methyl 3-butylimidazolium trifluoromethyl-sulfonyl imide \\
\hline EMIM- TFSI & 1-ethyl 3-methylimidazolium trifluoromethyl-sulfonyl imide \\
\hline BMIM-I & 1-methyl 3-butylimidazolium-iodide \\
\hline EG & Ethylene glycol \\
\hline PEG & Polyethylene glycol \\
\hline
\end{tabular}

lubricants)", In Applied Machining Technology, pp. 349-352, Springer, Berlin, Heidelberg, 2009.

\section{References}

[1] R. K. Jain, Production Technology, sixteenth ed., KHANNA publishers, Delhi, 1229.

[2] Tschätsch, H. and Reichelt, A., "Cutting fluids (coolants and
[3] Kuram, E., Ozcelik, B., Demirbas, E., Şik, E. and Tansel, I. N., "Evaluation of new vegetable-based cutting fluids on thrust force and surface roughness in drilling of AISI 304 using Taguchi method", Materials and Manufacturing Processes, vol. 26, pp. 1136-1146, 2011. 
[4] Sharif, M. N., Pervaiz, S. and Deiab, I., "Potential of alternative lubrication strategies for metal cutting processes: a review", The International Journal of Advanced Manufacturing Technology, vol. 89, pp. 2447-2479, 2017.

[5] Chinchanikar, S. and Choudhury, S. K., "Machining of hardened steel-experimental investigations, performance modeling and cooling techniques: a review", International Journal of Machine Tools and Manufacture, vol. 89, pp. 95-109, 2015.

[6] Chetan, Ghosh, S. and Rao, P. V., "Application of sustainable techniques in metal cutting for enhanced machinability: a review", Journal of Cleaner Production, vol. 100, pp. 17-34, 2015.

[7] Debnath, S., Reddy, M. M. and Yi, Q. S., "Environmental friendly cutting fluids and cooling techniques in machining: a review", Journal of cleaner production, vol. 83, pp. 33-47, 2014.

[8] Sharma, A. K., Tiwari, A. K. and Dixit, A. R., "Effects of Minimum Quantity Lubrication (MQL) in machining processes using conventional and nanofluid based cutting fluids: A comprehensive review", Journal of Cleaner Production, vol. 127, pp. 1-18, 2016.

[9] Benedicto, E., Carou, D. and Rubio, E. M., "Technical, economic and environmental review of the lubrication/cooling systems used in machining processes", Procedia engineering, vol. 184, pp. 99-116, 2017.

[10] Krolczyk, G. M., Maruda, R. W., Krolczyk, J. B., Wojciechowski, S., Mia, M., Nieslony, P. and Budzik, G., "Ecological trends in machining as a key factor in sustainable production-a review", Journal of Cleaner Production, vol. 218, pp. 601-615, 2019.

[11] Tai, B. L., Stephenson, D. A., Furness, R. J. and Shih, A. J., "Minimum quantity lubrication (MQL) in automotive powertrain machining”, Procedia CIRP, vol. 14, pp. 523-528, 2014.

[12] Schey, J. A., "Introduction to Manufacturing Processes", Third ed., Singapore: Mc Graw Hill, 2000.

[13] Shashidhara, Y. M. and Jayaram, S. R., "Vegetable oils as a potential cutting fluid-an evolution", Tribology International, vol. 43, pp. 1073-1081, 2010.

[14] Babic, D., Murray, D. B. and Torrance, A. A., "Mist jet cooling of grinding processes", International Journal of Machine Tools and Manufacture, vol. 45, pp. 1171-1177, 2005.

[15] An, Q. L., Fu, Y. C. and Xu, J. H., "Experimental study on turning of TC9 titanium alloy with cold water mist jet cooling" International Journal of Machine Tools and Manufacture, vol. 51, pp. 549-555, 2011.

[16] Lv, D., Xu, J., Ding, W., Fu, Y., Yang, C. and Su, H., "Tool wear in milling Ti40 burn-resistant titanium alloy using pneumatic mist jet impinging cooling", Journal of Materials Processing Technology, 229, pp. 641-650, 2016.

[17] Nandgaonkar, S., Gupta, T. V. K. and Joshi, S., "Effect of water oil mist spray (WOMS) cooling on drilling of Ti6Al4V alloy using Ester oil based cutting fluid", Procedia Manufacturing, vol. 6, pp. 71-79, 2016.

[18] Kaminski, J. and Alvelid, B., "Temperature reduction in the cutting zone in water-jet assisted turning", Journal of Materials
Processing Technology, vol. 106, pp. 68-73, 2000.

[19] Ezugwu, E. O., Machado, A. R., Pashby, I. R. and Wallbank, J., "The effect of high-pressure coolant supply when machining a heat-resistant nickel-based superalloy", Lubrication Engineering, vol. 47, pp. 751-757, 1991.

[20] Kramar, D. and Kopac, J., "High pressure cooling in the machining of hard-to-machine materials", Journal of Mechanical Engineering, vol. 55, pp. 685-694, 2009.

[21] Çolak, O., "Investigation on machining performance of Inconel 718 in high pressure cooling conditions", Journal of Mechanical Engineering, vol. 58, pp. 683-690, 2012.

[22] Çolak, O., "Optimization of machining performance in high-pressure assisted turning of Ti6Al4V alloy, " Journal of Mechanical Engineering, vol. 60, pp. 675-681, 2014.

[23] Xu, J., He, L., Su, H. and Zhang, L., "Tool wear investigation in high-pressure jet coolant assisted machining Ti2AlNb intermetallic alloys based on FEM", International Journal of Lightweight Materials and Manufacture, vol. 1, pp. 219-228, 2018.

[24] Alaxender, A., Varadarajan, A. S. and Philip, P. K., "Hard turning with minimum cutting fluid: a viable green alternative on the shop floor," In Proc. of the 18th AIMTDR (pp. 152-155), 1998.

[25] Cayli, T., Klocke, F. and Döbbeler, B., "Increasing Energy Efficiency in Turning of Aerospace Materials with High-Pressure Coolant Supply", Procedia Manufacturing, vol. 21, pp. 405-412, 2018.

[26] Alagan, N. T., Zeman, P., Hoier, P., Beno, T. and Klement, U., "Investigation of micro-textured cutting tools used for face turning of alloy 718 with high-pressure cooling, "Journal of Manufacturing Processes, vol. 37, pp. 606-616, 2019.

[27] Busch, K., Hochmuth, C., Pause, B., Stoll, A. and Wertheim, R., "Investigation of cooling and lubrication strategies for machining high-temperature alloys, " Procedia CIRP, vol. 41, pp. 835-840, 2016.

[28] Sørby, K. and Vagnorius, Z., "High-Pressure Cooling in Turning of Inconel 625 with Ceramic Cutting Tools", Procedia CIRP, vol. 77, pp. 74-77, 2018.

[29] Ezugwu, E. O. and Bonney, J., "Effect of high-pressure coolant supplies when machining nickel-base, Inconel 718, alloy with ceramic tools", Tribology transactions, vol. 46, pp. 580-584, 2003.

[30] Ezugwu, E. O., Bonney, J., Fadare, D. A. and Sales, W. F., "Machining of nickel-base, Inconel 718, alloy with ceramic tools under finishing conditions with various coolant supply pressures", Journal of Materials Processing Technology, vol. 162, pp. 609-614, 2005.

[31] Bruni, C., Forcellese, A., Gabrielli, F. and Simoncini, M., "Effect of the lubrication-cooling technique, insert technology and machine bed material on the workpart surface finish and tool wear in finish turning of AISI 420B, " International Journal of Machine Tools and Manufacture, vol. 46, pp. 1547-1554. 2006.

[32] Raykar, S. J., D'Addona, D. M. and Kramar, D., "Analysis of surface topology in dry machining of EN-8 steel", Procedia materials science, vol. 6, pp. 931-938, 2014. 
[33] Rubio, E. M., Villeta, M., Carou, D. and Saá, A., "Comparative analysis of sustainable cooling systems in intermittent turning of magnesium pieces", International journal of precision engineering and manufacturing, vol. 15, pp. 929-940, 2014.

[34] List, G., Nouari, M., Géhin, D., Gomez, S., Manaud, J. P., Le Petitcorps, Y. and Girot, F., "Wear behavior of cemented carbide tools in dry machining of aluminium alloy", Wear, vol. 259, pp. 1177-1189, 2005

[35] Bermudo, C., Trujillo, F. J., Herrera, M. and Sevilla, L., "Parametric analysis of the Ultimate Tensile Strength in dry machining of UNS A97075 Alloy, " Procedia Manufacturing, vol. 13 , pp. 81-88, 2017.

[36] Davoodi, B. and Tazehkandi, A. H., "Experimental investigation and optimization of cutting parameters in dry and wet machining of aluminum alloy 5083 in order to remove cutting fluid", Journal of Cleaner Production, vol. 68, pp. 234-242. 2014

[37] Devillez, A., Le Coz, G., Dominiak, S. and Dudzinski, D., "Dry machining of Inconel 718, workpiece surface integrity", Journal of Materials Processing Technology, vol. 211, pp. $1590-1598,2011$

[38] Venkatesan, K. and Thakur, A., "A Comparative Study on Machinability Characteristics in Dry Machining Of Nimonic 263 Alloy Using Coated Carbide Inserts". Materials Today: Proceedings, vol. 5, pp. 12443-12452, 2018

[39] Sugihara, T., Singh, P. and Enomoto, T., "Development of novel cutting tools with dimple textured surfaces for dry machining of aluminum alloys", Procedia Manufacturing, vol. 14, pp. 111-117, 2017.

[40] Niketh, S. and Samuel, G. L., "Drilling performance of micro textured tools under dry, wet and MQL condition", Journal of Manufacturing Processes, vol. 32, pp. 254-268, 2018.

[41] Elmunafi, M. H. S., Kurniawan, D. and Noordin, M. Y., "Use of castor oil as cutting fluid in machining of hardened stainless steel with minimum quantity of lubricant", Procedia CIRP, vol. 26, pp. 408-411, 2015.

[42] Park, K. H., Olortegui-Yume, J., Yoon, M. C. and Kwon, P., “A study on droplets and their distribution for minimum quantity lubrication (MQL) ", International Journal of Machine Tools and Manufacture, vol. 50, pp. 824-833, 2010.

[43] Sai, S. S., Manoj Kumar, K. and Ghosh, A., "Assessment of spray quality from an external mix nozzle and its impact on SQL grinding performance", International Journal of Machine Tools and Manufacture, vol. 89, pp. 132-141, 2015.

[44] Sarıkaya, M. and Güllü, A., "Taguchi design and response surface methodology based analysis of machining parameters in CNC turning under MQL", Journal of Cleaner Production, vol. 65, pp. 604-616, 2014.

[45] Rahim, E. A., Ibrahim, M. R., Rahim, A. A., Aziz, S. and Mohid, Z., "Experimental investigation of minimum quantity lubrication (MQL) as a sustainable cooling technique", Procedia CIRP, vol. 26, pp. 351-354, 2015.

[46] Dureja, J. S., Singh, R., Singh, T., Singh, P., Dogra, M. and Bhatti, M. S., "Performance evaluation of coated carbide tool in machining of stainless steel (AISI 202) under minimum quantity lubrication (MQL) ", International Journal of Precision Engineering and Manufacturing-Green Technology, vol. 2, pp. 123-129, 2015.

[47] Sakharkar, S. N. and Pawade, R. S., "Effect of Machining Environment on Turning Performance of Austempered Ductile Iron", CIRP Journal of Manufacturing Science and Technology, vol. 22, pp. 49-65, 2018.

[48] Nouioua, M., Yallese, M. A., Khettabi, R., Belhadi, S. and Mabrouki, T., "Comparative assessment of cooling conditions, including MQL technology on machining factors in an environmentally friendly approach", The International Journal of Advanced Manufacturing Technology, vol. 91, pp. 3079-3094, 2017.

[49] Ekinovic, S., Prcanovic, H. and Begovic, E., "Investigation of influence of MQL machining parameters on cutting forces during MQL turning of carbon steel St52-3", Procedia engineering, vol. 132, pp. 608-614, 2015.

[50] Brinksmeier, E., Pecat, O. and Rentsch, R., "Quantitative analysis of chip extraction in drilling of Ti6A14V," CIRP Annals, vol. 64, pp. 93-96, 2015.

[51] Tamang, S. K., Chandrasekaran, M. and Sahoo, A. K., "Sustainable machining: an experimental investigation and optimization of machining Inconel 825 with dry and MQL approach", Journal of the Brazilian Society of Mechanical Sciences and Engineering, vol. 40, pp. 374. 2018.

[52] Khatri, A. and Jahan, M. P., "Investigating tool wear mechanisms in machining of Ti-6Al-4V in flood coolant, dry and MQL conditions", Procedia Manufacturing, 26, pp. 434-445, 2018.

[53] Viswanathan, R., Ramesh, S. and Subburam, V., "Measurement and optimization of performance characteristics in turning of $\mathrm{Mg}$ alloy under dry and MQL conditions", Measurement, vol. 120, pp. 107-113, 2018.

[54] Chetan, Ghosh, S. and Rao, P. V., "Specific cutting energy modeling for turning nickel-based Nimonic 90 alloy under MQL condition", International Journal of Mechanical Sciences, vol. 146, pp. 25-38, 2018.

[55] Tai, B. L., "Workpiece temperature during deep-hole drilling of cast iron using high air pressure minimum quantity lubrication", Journal of Manufacturing Science and Engineering, vol. 135, pp. 1-7, 2013.

[56] Sakharkar, S. N. and Pawade, R. S., "Effect of Machining Environment on Turning Performance of Austempered Ductile Iron", CIRP Journal of Manufacturing Science and Technology, vol. 22, pp. 49-65, 2018.

[57] Hadad, M. and Sharbati, A., "Thermal aspects of environmentally friendly-MQL grinding process", Procedia CIRP, vol. 40, pp. 509-515, 2016.

[58] Chakule, R. R., Chaudhari, S. S. and Talmale, P. S., "Evaluation of the effects of machining parameters on MQL based surface grinding process using response surface methodology", Journal of Mechanical Science and Technology, vol. 31, pp. 3907-3916, 2017.

[59] Coupland, J. N. and McClements, D. J., "Physical properties of liquid edible oils", Journal of the American Oil Chemists' Society, vol. 74, pp. 1559-1564, 1997.

[60] Rahim, E. A. and Sasahara, H., "A study of the effect of palm oil as MQL lubricant on high speed drilling of titanium alloys", Tribology International, vol. 44, pp. 309-317, 2011. 
[61] Yıldırım, C.. V., Kıvak, T., Sarıkaya, M. and Erzincanlı, F., "Determination of MQL parameters contributing to sustainable machining in the milling of nickel-base superalloy waspaloy", Arabian Journal for Science and Engineering, vol. 42, pp. 4667-4681, 2017.

[62] Zhang, S., Li, J. F. and Wang, Y. W., "Tool life and cutting forces in end milling Inconel 718 under dry and minimum quantity cooling lubrication cutting conditions", Journal of Cleaner Production, vol. 32, pp. 81-87, 2012.

[63] Al-Wajidi, W., Deiab, I., Defersha, F. M. and Elsayed, A., "Effect of MQL on the microstructure and strength of friction stir welded $6061 \mathrm{Al}$ alloy, " The International Journal of Advanced Manufacturing Technology, vol. 101, pp. 901-912, 2019.

[64] Sampaio, M. A., Machado, A. R., Laurindo, C. A. H., Torres, R. D. and Amorim, F. L., "Influence of minimum quantity of lubrication (MQL) when turning hardened SAE 1045 steel: a comparison with dry machining", The International Journal of Advanced Manufacturing Technology, vol. 98, pp. 959-968, 2018.

[65] Agrawal, S. M. and Patil, N. G., "Experimental study of non-edible vegetable oil as a cutting fluid in machining of M2 Steel using MQL, " Procedia Manufacturing, vol. 20, pp. 207-212, 2018.

[66] Vardhaman, B. A., Amarnath, M., Jhodkar, D., Ramkumar, J., Chelladurai, H. and Roy, M. K., "Influence of coconut oil on tribological behavior of carbide cutting tool insert during turning operation", Journal of the Brazilian Society of Mechanical Sciences and Engineering, vol. 40, pp. 450, 2018.

[67] Talib, N. and Rahim, E. A., "Performance evaluation of chemically modified crude Jatropha oil as a bio-based metalworking fluid for machining process", Procedia CIRP, vol. 26, pp. 346-350, 2015.

[68] Talib, N. and Rahim, E. A., "Performance of modified Jatropha oil in combination with hexagonal boron nitride particles as a bio-based lubricant for green machining", Tribology International, vol. 118, pp. 89-104, 2018.

[69] Reddy, N. S. K.; Rao, P. V., "Experimental investigation to study the effect of solid lubricants on cutting forces and surface quality in end milling", International Journal of Machine Tools \& Manufacture, vol. 46, pp. 189-198, 2006.

[70] Paturi, U. M. R., Maddu, Y. R., Maruri, R. R. and Narala, S. K. R., "Measurement and analysis of surface roughness in WS2 solid lubricant assisted minimum quantity lubrication (MQL) turning of Inconel 718”, Procedia CIRP, vol. 40, pp. 138-143, 2016.

[71] Gunda, R. K., Reddy, N. S. K. and Kishawy, H. A., "A novel technique to achieve sustainable machining system", Procedia CIRP, vol. 40, pp. 30-34, 2016.

[72] Marques, A., Suarez, M. P., Sales, W. F. and Machado, Á. R., "Turning of Inconel 718 with whisker-reinforced ceramic tools applying vegetable-based cutting fluid mixed with solid lubricants by MQL", Journal of Materials Processing Technology, vol. 266, pp. 530-543, 2019.

[73] Sterle, L., Kalin, M. and Pušavec, F., "Performance Evaluation of Solid Lubricants under Machining-Like Conditions", Procedia CIRP, vol. 77, pp. 401-404, 2018.

[74] Sharma, A. K., Tiwari, A. K., Dixit, A. R., Singh, R. K. and Singh, M., "Novel uses of alumina/graphene hybrid nanoparticle additives for improved tribological properties of lubricant in turning operation", Tribology International, vol. 119, pp. 99-111, 2018.

[75] Salimi-Yasar, H., Heris, S. Z. and Shanbedi, M., "Influence of soluble oil-based $\mathrm{TiO}_{2}$ nanofluid on heat transfer performance of cutting fluid", Tribology International, vol. 112, pp. 147-154, 2017.

[76] JAFARI, N. M., Shekarian, E., Tarighaleslami, A. H., Khodaverdi, F. and BADINI, P. M., "The impact of application of heat transfer enhancement technologies on design of shell and tube heat exchangers", Iran. Journal of Chemical Engineering, vol. 14, pp. 64-74, 2015.

[77] Uysal, A., Demiren, F. and Altan, E., “Applying minimum quantity lubrication (MQL) method on milling of martensitic stainless steel by using nano MoS2 reinforced vegetable cutting fluid", Procedia-Social and Behavioral Sciences, vol. 195, pp. 2742-2747, 2015

[78] Rabiei, F., Rahimi, A. R., Hadad, M. J. and Saberi, A., "Experimental evaluation of coolant-lubricant properties of nanofluids in ultrasonic assistant MQL grinding", The International Journal of Advanced Manufacturing Technology, vol. 93, pp. 3935-3953, 2017a.

[79] Wang, Y., Li, C., Zhang, Y., Yang, M., Li, B., Dong, L. and Wang, J., "Processing characteristics of vegetable oil-based nanofluid MQL for grinding different workpiece materials", International Journal of Precision Engineering and Manufacturing-Green Technology, vol. 5, pp. 327-339, 2018.

[80] Eltaggaz, A., Hegab, H., Deiab, I. and Kishawy, H. A., "Hybrid nano-fluid-minimum quantity lubrication strategy for machining austempered ductile iron (ADI)", International Journal on Interactive Design and Manufacturing (IJIDeM), vol. 12, pp. 1273-1281, 2018.

[81] Gutnichenko, O., Bushlya, V., Bihagen, S. and Ståhl, J. E., "Influence of $\mathrm{GnP}$ additive to vegetable oil on machining performance when MQL-assisted turning Alloy 718”, Procedia Manufacturing, vol. 25, pp. 330-337, 2018.

[82] Hegab, H., Darras, B. and Kishawy, H. A., "Sustainability assessment of machining with nano-cutting fluids", Procedia Manufacturing, vol. 26, pp. 245-254, 2018.

[83] Zhang, X., Li, C., Zhang, Y., Wang, Y., Li, B., Yang, M., Guo, S., Liu, G. and Zhang, N., "Lubricating property of MQL grinding of $\mathrm{Al}_{2} \mathrm{O}_{3} / \mathrm{SiC}$ mixed nanofluid with different particle sizes and microtopography analysis by cross-correlation", Precision Engineering, vol. 47, pp. 532-545, 2017.

[84] Zhang, Y., Li, C., Jia, D., Zhang, D. and Zhang, X., "Experimental evaluation of the lubrication performance of MoS2/CNT nanofluid for minimal quantity lubrication in Ni-based alloy grinding", International Journal of Machine Tools and Manufacture, vol. 99, pp. 19-33, 2015.

[85] Lv, T., Huang, S., Hu, X., Ma, Y. and Xu, X., "Tribological and machining characteristics of a minimum quantity lubrication (MQL) technology using $\mathrm{GO} / \mathrm{SiO}_{2}$ hybrid nanoparticle water-based lubricants as cutting fluids", The International Journal of Advanced Manufacturing Technology, vol. 96, pp. 2931-2942, 2018.

[86] Rabiei, F. A. R. S. H. A. D., Rahimi, A. R. and Hadad, M., "Performance improvement of eco-friendly MQL technique by using hybrid nanofluid and ultrasonic-assisted grinding", The International Journal of Advanced Manufacturing Technology, vol. 93, pp. 1001-1015, $2017 \mathrm{~b}$. 
[87] Davis, B., Schueller, J. K. and Huang, Y., "Study of ionic liquid as effective additive for minimum quantity lubrication during titanium machining", Manufacturing Letters, 5, pp. 1-6, 2015.

[88] Goindi, G. S., Chavan, S. N., Mandal, D., Sarkar, P. and Jayal, A. D., "Investigation of ionic liquids as novel metalworking fluids during minimum quantity lubrication machining of a plain carbon steel", Procedia CIRP, 26, pp. 341-345, 2015.

[89] Pham, M. Q., Yoon, H. S., Khare, V. and Ahn, S. H., "Evaluation of ionic liquids as lubricants in micro millingprocess capability and sustainability", Journal of cleaner production, vol. 76, pp. 167-173, 2014.

[90] Sani, A. S. A., Rahim, E. A., Sharif, S. and Sasahara, H., "Machining performance of vegetable oil with phosphonium-and ammonium-based ionic liquids via MQL technique", Journal of Cleaner Production, vol. 209, pp. 947-964, 2019.

[91] Huang, S., Wang, Z., Yao, W. and Xu, X., “Tribological evaluation of contact-charged electrostatic spray lubrication as a new near-dry machining technique", Tribology International, vol. 91, pp. 74-84, 2015.

[92] Mia, M., Razi, M. H., Ahmad, I., Mostafa, R., Rahman, S. M., Ahmed, D. H., Dey, P. R. and Dhar, N. R., "Effect of time-controlled MQL pulsing on surface roughness in hard turning by statistical analysis and artificial neural network", The International Journal of Advanced Manufacturing Technology, vol. 91, pp. 3211-3223, 2017.

[93] Mia, M., Singh, G., Gupta, M. K. and Sharma, V. S., "Influence of Ranque-Hilsch vortex tube and nitrogen gas assisted MQL in precision turning of Al 6061-T6", Precision Engineering, vol. 53, pp. 289-299, 2018.

[94] Xu, X., Huang, S., Wang, M. and Yao, W., “A study on process parameters in end milling of AISI-304 stainless steel under electrostatic minimum quantity lubrication conditions", The International Journal of Advanced Manufacturing Technology, vol. 90, pp. 979-989, 2017.

[95] Dhar, N. R., Paul, S. and Chattopadhyay, A. B., "Machining of AISI 4140 steel under cryogenic cooling - tool wear, surface roughness and dimensional deviation", Journal of Materials processing technology, vol. 123, pp. 483-489, 2002.

[96] Dhar, N. R. and Kamruzzaman, M., "Cutting temperature, tool wear, surface roughness and dimensional deviation in turning AISI-4037 steel under cryogenic condition", International Journal of Machine Tools \& Manufacture, vol. 47, pp. 754-759, 2007.

[97] Fredj, N. B., Sidhom, H. and Braham, C., "Ground surface improvement of the austenitic stainless steel AISI 304 using cryogenic cooling", Surface and Coatings Technology, vol. 200, pp. 4846-4860, 2006

[98] Umbrello, D., Micari, F. and Jawahir, I. S., 2012, “The effects of cryogenic cooling on surface integrity in hard machining: A comparison with dry machining", CIRP annals, 61 (1), pp. 103-106.

[99] Manimaran, G. and Pradeepkumar, M., "Influence of cryogenic cooling on surface grinding of stainless steel 316", Cryogenics, vol. 59, pp. 76-83, 2014.

[100] Dinesh, S., Senthilkumar, V., Asokan, P. and Arulkirubakaran, D., "Effect of cryogenic cooling on machinability and surface quality of bio-degradable ZK60 Mg alloy", Materials \& design, vol. 87, pp. 1030-1036, 2015.

[101] Shokrani, A., Dhokia, V. and Newman, S. T., "Cryogenic high speed machining of cobalt chromium alloy", Procedia CIRP, vol. 46, pp. 404-407, 2016.

[102] Aramcharoen, A., "Influence of cryogenic cooling on tool wear and chip formation in turning of titanium alloy" Procedia CIRP, vol. 46, pp. 83-86, 2016.

[103] Yousfi, M., Outeiro, J. C., Nouveau, C., Marcon, B. and Zouhair, B., "Tribological behavior of PVD hard coated cutting tools under cryogenic cooling condition", Procedia CIRP, vol. 58, pp. 561-565, 2017.

[104] Isakson, S., Sadik, M. I., Malakizadi, A. and Krajnik, P., "Effect of cryogenic cooling and tool wear on surface integrity of turned Ti-6Al-4V”, Procedia CIRP, vol. 71, pp. 254-259, 2018.

[105] Mia, M., "Multi-response optimization of end milling parameters under through-tool cryogenic cooling condition", Measurement, vol. 111, pp. 134-145, 2017.

[106] Nie, G. C., Zhang, X. M., Zhang, D. and Ding, H., “An experimental study of the white layer formation during cryogenic assisted hard machining of AISI 52100 steel", Procedia CIRP, 77, pp. 223-226, 2018.

[107]Mia, M., Gupta, M. K., Lozano, J. A., Carou, D., Pimenov, D. Y., Królczyk, G., Khan, A. M. and Dhar, N. R., "Multi-objective optimization and life cycle assessment of eco-friendly cryogenic N2 assisted turning of Ti-6Al-4V", Journal of Cleaner Production, vol. 210, pp. 121-133, 2018.

[108] Sivaiah, P. and Chakradhar, D., "Performance improvement of cryogenic turning process during machining of 17-4 $\mathrm{PH}$ stainless steel using multi objective optimization techniques", Measurement, vol. 136, pp. 326-336, 2019.

[109] Dhananchezian, M., "Study the machinability characteristics of Nicked based Hastelloy C-276 under cryogenic cooling", Measurement, vol. 136, pp. 694-702, 2019.

[110] NALBANT, M. and YILDIZ, Y., "Effect of cryogenic cooling in milling process of AISI 304 stainless steel", Trans. Nonferrous Met. Soc. China, vol. 21, pp. 72-79, 2011.

[111] Murugappan, S., Arul, S. and Narayanan, S. K., "An experimental study on turning of AL6063 under cryogenic pre cooled condition”, Procedia CIRP, vol. 35, pp. 61-66, 2015.

[112] Biermann, D. and Hartmann, H., "Reduction of burr formation in drilling using cryogenic process cooling," Procedia CIRP, vol. 3, pp. 85-90, 2012.

[113] Cordes, S., Hübner, F. and Schaarschmidt, T., "Next generation high performance cutting by use of carbon dioxide as cryogenics", Procedia CIRP, vol. 14, pp. 401-405, 2014.

[114] Rahim, E. A., Rahim, A. A., Ibrahim, M. R. and Mohid, Z., "Experimental investigation of supercritical carbon dioxide $\left(\mathrm{SCCO}_{2}\right)$ performance as a sustainable cooling technique", Procedia CIRP, vol. 40, pp. 637-641, 2016.

[115] Pereira, O., Rodríguez, A., Barreiro, J., Fernández-Abia, A. I. and de Lacalle, L. N. L., "Nozzle design for combined use of MQL and cryogenic gas in machining”, International journal of precision engineering and manufacturing-green technology, vol. 4, pp. 87-95, 2017. 
[116] Park, K. H., Suhaimi, M. A., Yang, G. D., Lee, D. Y., Lee, S. W. and Kwon, P., "Milling of titanium alloy with cryogenic cooling and minimum quantity lubrication (MQL)", International Journal of Precision Engineering and Manufacturing, vol. 18, pp. 5-14, 2017.

[117] Hanenkamp, N., Amon, S. and Gross, D., "Hybrid Supply
System for Conventional and $\mathrm{CO}_{2} / \mathrm{MQL}-$ based Cryogenic Cooling", Procedia CIRP, vol. 77, pp. 219-222, 2018.

[118] Iturbe, A., Hormaetxe, E., Garay, A. and Arrazola, P. J., "Surface integrity analysis when machining inconel 718 with conventional and cryogenic cooling", Procedia CIRP, 45, pp. 67-70, 2016. 